\title{
The incorporation of Māori environmental values as part of the Ruamāhanga Whaitua Implementation Programme in the Wellington Region, Aotearoa New
}

\section{Zealand}

Bryn Cal Hickson Rowden

A 90 point thesis submitted to Victoria University of Wellington in partial fulfilment of requirements for the degree of Master of Environmental Studies

School of Geography, Environment and Earth Sciences

Te Kura Tātai Aro Whenua

Victoria University of Wellington

Te Whare Wānanga o Te Ūpoko o Te Ika a Māui

April 2018 




\section{Abstract}

In recent years, there has been significant efforts to create frameworks in which Māori values are incorporated as part of environmental management processes in Aotearoa New Zealand (Forster, 2014; Harmsworth et al., 2016). This research explores the factors that influence the incorporation of Māori values at the local government level, and what barriers Māori values face to being incorporated in environmental management. This research focused on a case study of the Ruamāhanga Whaitua Committee Implementation Programme process in the Wellington region.

Semi-structured interviews were used to collect information on the opinions of members of the Ruamāhanga Whaitua Committee. The interviews were analysed using a critical theory approach. The research found that there was a clear discrepancy between the values and behaviours expressed by some non-Māori members of the Committee. The result of such a discrepancy was that Māori values were not sufficiently part of environmental decision making. Such a discrepancy was a result of the political structures of the Regional Council's Whaitua Implementation Programme process. The majority of the decision-making power was found to be situated 'higher' up in the organisation, outside of the Committee. Overall this research found that there are important opportunities to make sure iwi values are not only included, but form the basis of decisions.

Keywords: Māori environmental management, decolonisation, local level government, community management. 


\section{Acknowledgements}

I would like to acknowledge the following people, without whose support this research would not have been possible.

Firstly, I would like to thank the representatives from Ngāti Kahungunu ki Wairarapa and Rangitāne o Wairarapa, who took the time to engage with me about my research intentions, and for their subsequent support of the research. This research would have never gone ahead without such support.

I am enormously thankful to the interview participants from the Ruamāhanga Whaitua Committee who gave up their time to share knowledge, stories and insights with me. All of which were invaluable to the research. I would also like to thank the Greater Wellington Regional Council, and in particular Brett Cockeram, for the initial introduction to the Ruamāhanga Whaitua Committee.

My supervisor, Dr. Amanda Thomas who's support, encouragement and patience throughout this process has been unwavering. Your ability to challenge ideas and encourage thought has been the most brilliant tool for helping me to make this thesis what it has become.

Words cannot convey my gratitude to my father, Ashley Rowden whose advice, comments and unrelenting support has reinforced how lucky I am to have such a loving family. Both my parents have supported me through not only this thesis study, but the whole of my university career. I will never be able to fully covey my gratitude to you both for giving me the opportunity to chase without bounds, the things that interest me. I also wish to thank my partner Mel, whose strength, especially in the latter parts of this process, has always kept the end in sight. And my friends, whose support and constant encouragement made everything that much easier.

Finally thank you to my colleagues Chantal, Ria, Rach, Alyssa, Nic and Leo whose discussions have always entertained, and whose thoughts and suggestions have been invaluable. 


\section{Table of contents}

Acknowledgements.....

The cultural, historical and political context for environmental management in Aotearoa New Zealand.

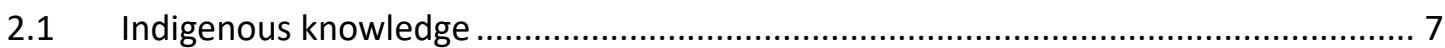

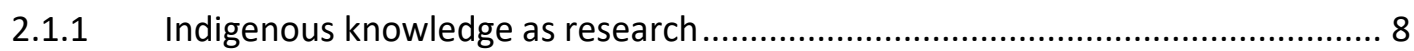

2.1.2 The boundary between Indigenous knowledge and Western science ................. 9

2.2 The politics of Māori environmental management ................................................... 11

2.2.1 Māori beliefs, customs and values................................................................ 11

2.2.2 Colonialism and environmental management.................................................. 13

2.2.3 Post-colonial environmental management ..................................................... 14

2.2.4 Aotearoa New Zealand as a bicultural nation.................................................... 16

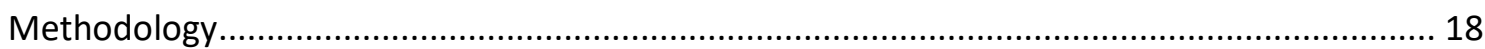

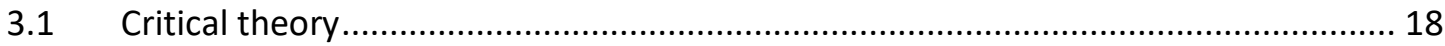

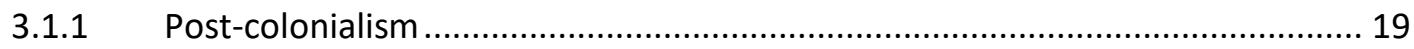

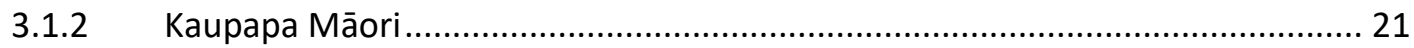

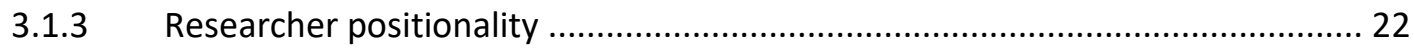

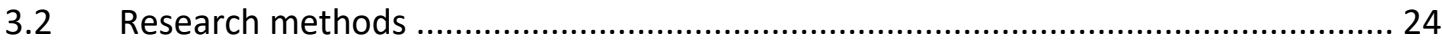

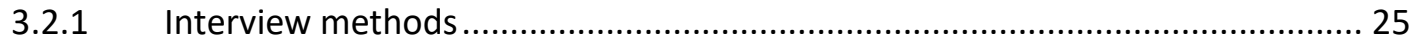

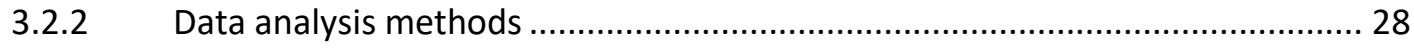

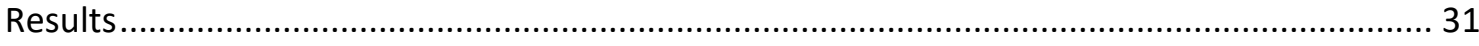

4.1 Ruamāhanga Whaitua Committee values ………..................................................... 31

4.2 The prioritisation of values and committee make-up .................................................. 33

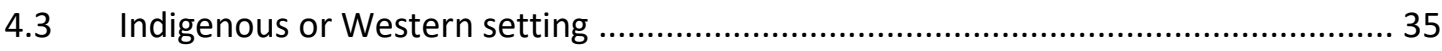




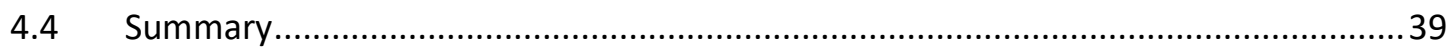

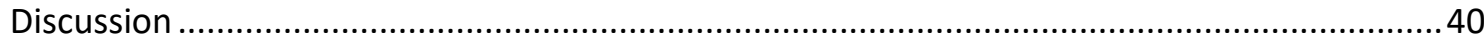

5.1 Values of the Ruamāhanga Whaitua Committee ........................................................40

5.1.1 Discrepancy between values and behaviour ................................................... 41

5.1.2 Politics as a contributor to the value-behaviour discrepancy ............................42

5.1.3 Capitalism as a contributor to the value-behaviour discrepancy ........................44

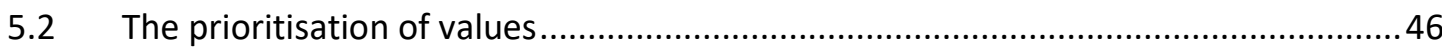

5.2.1 Colonial histories and postcolonialism ........................................................... 47

5.2.2 Power outside of community-level environmental management ......................48

5.2.3 Decolonisation in environmental management ..................................................50

5.2.4 Power within community environmental management .....................................53

5.3 The language of values and Indigenous and Western viewpoints ...............................54

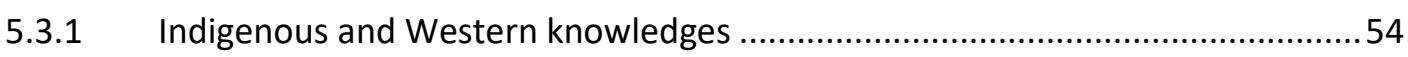

5.3.2 Aotearoa New Zealand and Māori values ...........................................................56

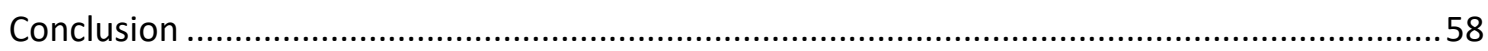

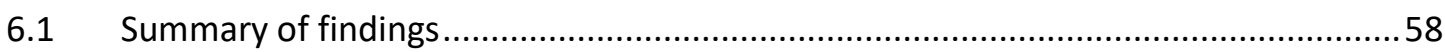

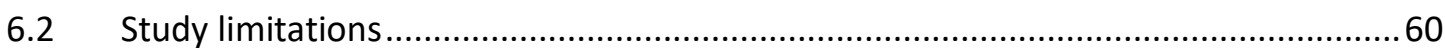

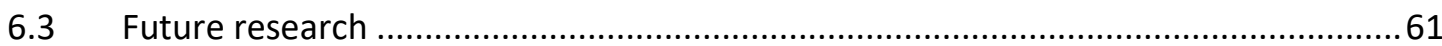

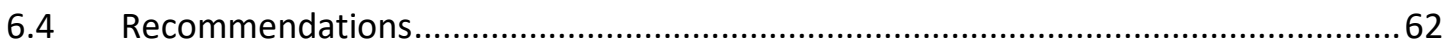

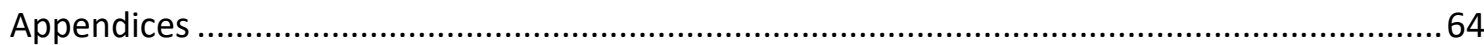

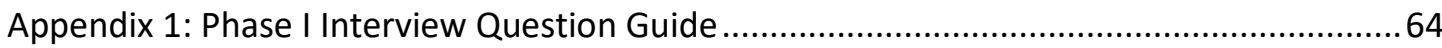

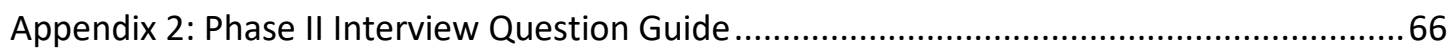

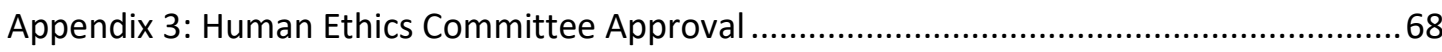

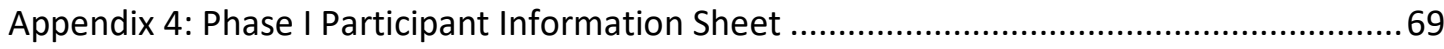

Appendix 5: Phase II Participant Information Sheet ............................................................. 71

Appendix 6: Participant Consent Form.............................................................................. 73

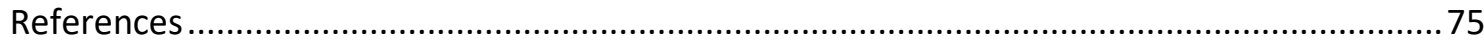




\section{Glossary}

The following glossary definitions have been drawn from the Māori Dictionary Online.

atua - ancestor with continuing influence, god, demon, supernatural being, deity, ghost, object of superstitious regard, strange being - although often translated as 'god' and now also used for the Christian God.

hapū - kinship group, clan, tribe, subtribe - section of a large kinship group and the primary political unit in traditional Māori society.

hui - gathering, meeting, assembly, seminar, conference.

iwi - extended kinship group, tribe, nation, people, nationality, race - often refers to a large group of people descended from a common ancestor and associated with a distinct territory.

kaitiaki - trustee, minder, guard, custodian, guardian, caregiver, keeper, steward.

kaitiakitanga - guardianship, stewardship, trusteeship, trustee.

ki uta ki tai - "from the mountains to the sea".

mahinga kai - garden, cultivation, food-gathering place.

mahitahi - partnership.

mana - prestige, authority, control, power, influence, status, spiritual power, charisma.

marae - courtyard - the open area in front of the wharenui, where formal greetings and discussions take place. Often also used to include the complex of building around the marae.

mātauranga Māori - Māori knowledge, wisdom, understanding, skill.

mauri - life principle, life force, vital essence, special nature, a material symbol of a life principle, source of emotions - the essential quality and vitality of a being or entity.

Pākehā - English, foreign, European, exotic, foreigner, alien. 
rangatiratanga - chieftainship, right to exercise authority, chiefly autonomy, chiefly authority, ownership, leadership of a social group, domain of the rangatira, noble birth, attributes of a chief.

takiwā - district, area, territory, vicinity, region.

tangata whenua - local people, hosts, Indigenous people - born of the whenua, i.e. of the placenta and of the land where the people's ancestors have lived and where their placenta are buried.

te ao Māori - the Māori world.

Te Upoko Taiao - Natural Resources Plan Committee.

wairua - spirit, soul - spirit of a person which exists beyond death. It is the non-physical spirit, distinct from the body and the mauri.

whakapapa - genealogy, genealogical table, lineage, descent.

whanaungatanga - relationship, kinship, sense of family connection - a relationship through shared experiences and working together which provides people with a sense of belonging. 



\section{Chapter One}

\section{Introduction}

Freshwater management in Aotearoa New Zealand ${ }^{1}$ has significantly reformed since the 1980s, including substantive changes to the philosophy and objectives for water management (Memon, 1997). However, these changes were not always inclusive of Māori. In recent years, sustained action by Māori has seen this lack of inclusion begin to change, with environmental management frameworks increasingly recognising Māori and tangata whenua (Harmsworth \& Roskruge, 2014). The inclusion of Māori perspectives in environmental management has largely been demonstrated through local government legislation, including in the case of the Wellington region, the Proposed Natural Resources Plan.

However, colonialism continues to shape society and environmental management in Aotearoa New Zealand (Ginn, 2008). Underpinning colonialism, is the idea that Eurocentric worldviews are superior, or even the only worldview (Smith, 2005). Colonisation has involved the violent dislocation from land, loss of rights to mahinga kia (food gathering places), deceit, and racism by the state (Kanwar et al., 2016; Tipa, 2009). All of these impacts have served to alienate many Māori from resources that they have never given up sovereignty over. Through Māori activism - such as the Māori Land March (Walker, 1984), Bastion Point protest (Harris, 2004), the Raglan Golf Course protest (Workman, 2016) - the Crown has been forced to take Māori rights seriously, including the Māori right to "have a say" over the environment. Power and politics around environmental management can influence how different values are included in management outcomes (Brosius et al., 2005). The national political climate in New Zealand for the last 10 years (2008-2017) has been dominated by the National Party who have focused on economic promotion, rather than environmental sustainability (Nel,

\footnotetext{
${ }^{1}$ While not officially recognised as the name of New Zealand, I have chosen to use Aotearoa New Zealand in this thesis as a way to acknowledge that there are two names for the country, and to use both simultaneously can serve to equalise the standing of both.
} 
2014). In environmental decision making, this position leads to the privilege of particular perspectives, values and approaches.

Arguably, some of the most important debates about Māori involvement in environmental decision making have been in the realm of freshwater. This research focuses on one case study - a community freshwater management process for the Ruamāhanga catchment in the Wairarapa region of Aotearoa New Zealand. The Ruamāhanga Whaitua Committee is made up of community members and local level government employees, and seeks to produce freshwater management decisions of the Ruamāhanga catchment. This study examines the inclusion of Māori values in the Ruamāhanga Whaitua Committee recommendations to the Greater Wellington Regional Council's Whaitua Implementation Programme process. This research focuses on values because the Ruamāhanga Whaitua Committee has taken a value-based approach to environmental management. To understand the formation and processes relating to the Ruamāhanga Whaitua Committee, this chapter will begin by discussing the Greater Wellington Regional Council's Proposed Natural Resource Plan. The chapter will then continue by outlining the Wellington Region's Whaitua Committees, the Whaitua Implementation Programme, and the Ruamāhanga Whaitua Committee. The chapter will finish with the study aim and objectives.

\subsection{Proposed Natural Resources Plan}

Regional plans enable a regional council to carry out its functions under the Resource Management Act (1991) (RMA). Regional plans must give effect to the RMA, National Policy Statements and the Regional Policy Statement. When preparing a regional plan, a regional council must also take into account any relevant planning documents that are recognised by iwi (extended Māori kinship group) authorities and lodged with the council. Such planning documents include memoranda of partnership, for example like the memorandum established in 2013 between iwi in the Wellington Region and the Greater Wellington Regional Council. 
In 2013 the Greater Wellington Regional Council started a review process of the regional plans for the Wellington Region. As a result of this review, the Proposed Natural Resources Plan for the Wellington Region was developed. On 31 July 2015, the proposed plan was approved by the council for public notification. The Proposed Natural Resources Plan combines coastal and regional plans, and well as incorporating regulatory and non-regulatory practices.

The Proposed Natural Resources Plan identifies five distinct river catchment areas or whaitua within the Wellington Region. The five whaitua are the Wairarapa Coast, Ruamāhanga, Wellington Harbour and Hutt Valley, Te Awarua-o-Porirua, and Kāpiti Coast (Figure 1). One of the aims of the Proposed Natural Resources Plan process is to provide a decentralised approach to freshwater environmental management, through management groups known as Whaitua Committees. The idea behind the Whaitua Committees is that they will use an integrated approach that includes and involves iwi and community members to manage the freshwater environment (GWRC, 2018b). The Whaitua Committees will provide the basis for the Greater Wellington Regional Council's Proposed Natural Resources Plan to implement the National Policy Statement for Freshwater Management (2014).

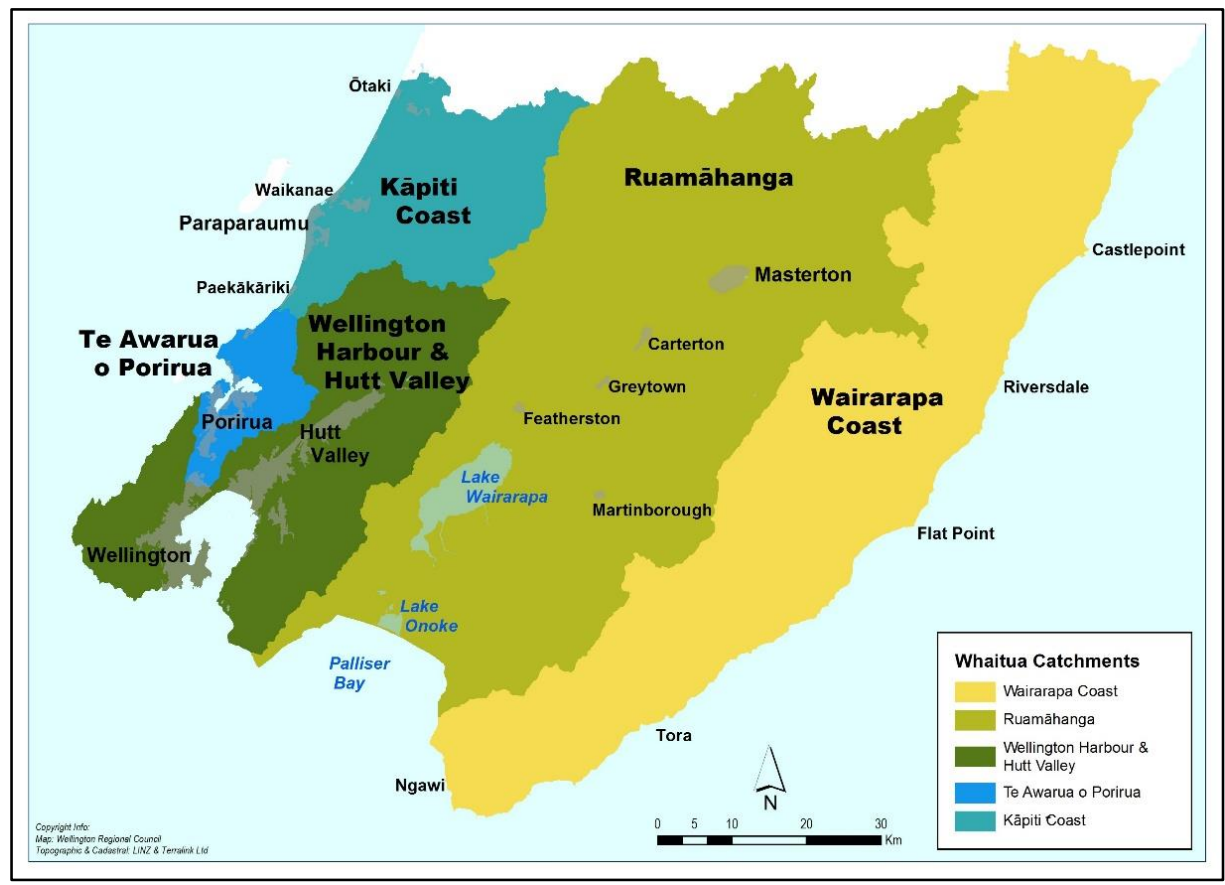

Figure 1: Map of the five whaitua or catchments in the Wellington Region (Source: Greater Wellington Regional Council, 2018). 


\subsection{The Whaitua Committee programme}

The aim of the Whaitua Committees is to work in partnership with tangata whenua (local Indigenous people) to develop recommendations that are guided by the principles developed through the regional plan review process by Te Upoko Taiao (Natural Resources Committee). Te Upoko Taiao comprises of six elected Greater Wellington councillors and six appointed members from the region's iwi. Each of the region's six iwi was asked by the council to nominate somebody to be a part of Te Upoko Taiao. The inclusion of iwi is a product of the active relationship between the regional council and tangata whenua, as well as its legislative mandate under the Local Government Act (2002). The Local Government Act (2002) includes several provisions that require regional councils to account for the principles of the Treaty of Waitangi (1840), with the aim of maintaining or improving opportunities for Māori to be involved in local government decision making. Te Upoko Taiao identifies five guiding principles for the Whaitua Committees, which are: Ki uta ki tia (connectedness); wairua (identity); kaitiaki (guardianship); tō mātou whakapono (judgement-based knowledge); and mahitahi (partnership) (GWRC, 2018a). These guiding principles were used by the Whaitua Committees to develop their input into each Whaitua Implementation Programme.

\subsection{Whaitua Implementation Programme}

Each Whaitua Implementation Programme aims to describe the ways in which the people from the whaitua want the water to be managed, both now and by future generations through a "range of integrated tools, polices and strategies" (GWRC, 2018b). It is important here to identify that the Whaitua Committees produce regulatory recommendations for each Whaitua Implementation Programme that go to Te Upoko Taiao and the Greater Wellington Regional Council for approval. If approved, the Whaitua Implementation Programme is included in the Proposed Natural Resource Plan change process, and will become a chapter in the Regional Council's Natural Resource Plan. Each of the Whaitua Committees are at different stages in the Whaitua Implementation Programme process. The Ruamāhanga Whaitua Committee was established in December 2013, and Te Awarua-o-Porirua's Committee in December 
2014. The Whaitua Committees of Wairarapa Coast, Wellington Harbour and Hutt Valley and, Kāpiti Coast are yet to be established.

\subsection{Ruamāhanga Whaitua Committee}

Out of the five Whaitua Committees, the Ruamāhanga Whaitua Committee was chosen as the focus of this research because it was the committee that had progressed furthest in the Whaitua Implementation Programme process. The Ruamāhanga Whaitua Committee consists of a group of people and regional representatives connected to the Ruamāhanga whaitua. Committee members were appointed by the Greater Wellington Regional Council. The Committee consists of fourteen members, including one elected and one appointed member from Te Upoko Taiao, two iwi authority representatives, one member nominated by each territorial authority, and up to seven members from the community with a range of backgrounds (GWRC, 2018a). The two iwi authorities within the Ruamāhanga whaitua are Ngāti Kahungunu ki Wairarapa and Rangitāne o Wairarapa. It should also be noted that there are members of the Ruamāhanga Whaitua Committee who are Māori but do not sit on the committee as iwi representatives. A chairperson was elected by the full Ruamāhanga Whaitua Committee, and committee members serve on the committee for its duration of existence which finishes when the Whaitua Implementation Programme document is completed, which will most likely be in the latter half of 2018. Importantly the committee decides on recommendations for the Ruamāhanga Whaitua Implementation Programme by consensus.

\subsection{Study aim and objectives}

The inclusion and incorporation of Māori values as part of natural resource management in Aotearoa New Zealand faces a number of barriers. Māori values are generally viewed as auxiliary or secondary information in environmental management decision making. Such a mind-set by environmental management actors in Aotearoa New Zealand has orientated the focus of this research. The overarching aim of this research is to understand what influences the incorporation of iwi values (as representative of Māori 
values) in the Greater Wellington Regional Council's Ruamāhanga Whaitua Committee's Whaitua Implementation Programme. The research aim was addressed by conducting a qualitative study focusing on the Ruamāhanga Whaitua Committee. The objectives of the study were to: (1) understand the power and political structures that are at play at a community-level in the environmental management setting. In particular, I sought to identify the origin and influences of these structures; (2) ascertain if the Ruamāhanga Whaitua Committee has been able to deliver the desired outcomes for Māori as part of the Whaitua Implementation Programme, or if there are aspects of the programme that can be improved on in order to achieve the greater inclusion of Māori values in the future. The research objectives were informed by two research questions: (i) how effective is the Ruamāhanga Whaitua Implementation Programme process at incorporating iwi environmental values in the freshwater management of the Ruamāhanga Whaitua? And, (ii) what barriers face iwi representatives on the Ruamāhanga Whaitua Committee from including iwi environmental values? The two research questions laid the foundation for the initial interviews that were undertaken with iwi members of the Ruamāhanga Whaitua Committee.

This research is timely because of the recent trends of cultural and political shifts in environmental management in Aotearoa New Zealand. The literature on such topics is expanding, and this study sits within the wider theme of environmental politics and decolonisation. Broadly, this study aims to contribute to the understanding of how Māori are included in freshwater management within the governmental systems of Aotearoa New Zealand. 


\section{Chapter Two}

\section{The cultural, historical and political context for environmental management in Aotearoa New}

\section{Zealand}

To understand the influences and processes that the Ruamāhanga Whaitua Committee faces when engaging in environmental management, a review of the current body of literature on Māori environmental management in Aotearoa New Zealand was undertaken. This chapter will address existing research about the past and current understanding about Indigenous knowledge of the environment, environmental management in a Māori context, and the politics involved in environmental management.

\subsection{Indigenous knowledge}

Indigenous knowledge and associated worldviews are dynamic and continually evolving (Henderson, 2000). In general, Indigenous knowledge can be characterised as arising from observations and interactions with both the biological and social environments, as well as interaction with spiritual elements of the environment (Getty, 2009; Henderson, 2000). Over the last 400 years there have been multiple attempts to describe and analyse Indigenous people's worldviews from a Eurocentric or Western perspective (Smith, 2005). Such discussion and analysis has resulted in Indigenous knowledge being ignored in environmental management because it is dismissed as folklore, and lacking any scientific basis (Getty, 2009; Smith, 2000; Smith, 2005). This approach to knowledge is fundamentally colonising and ignores the depth and complexity of Indigenous worldviews. 


\subsubsection{Indigenous knowledge as research}

Cardinal (2001) explains that Indigenous research methods and methodologies are as old as Indigenous people themselves, and that Indigenous cultures are rich with ways of gathering knowledge. Smith (2005) notes that one research approach to Indigenous knowledge is Kaupapa Māori, which is defined as culturally safe for its participants, and where existing institutions are critiqued for power relationships and social inequalities. Kaupapa Māori is a part of a wider tradition of work that is a response, and a challenge, to the dominance of Western scientific methodologies and practices (Cooper, 2012). Smith (2005) argues that Kaupapa Māori can occupy a scientific and social arena that has been historically antagonistic towards Māori knowledge production practices. Kaupapa Māori has the ability to break down and address the imbalances that Māori knowledge faces in science and society in Aotearoa New Zealand. Due to the power of colonialism and dominant Western discourses, Kaupapa Māori has had to continuously make a case for Māori knowledge production practices in Western scientific terms (Cooper, 2012). Kaupapa Māori will be discussed further in the subsequent chapter, but it is important to note that the literature highlights the challenges Kaupapa Mãori faces in the current environmental management setting within Aotearoa New Zealand.

The way knowledges and research approaches compete has been demonstrated in freshwater management. Gail Tipa (2009) argues that Indigenous communities hold distinct ideas around freshwater and so are particularly sensitive to its use and development. Freshwater, among other things, can impact Indigenous attachment to the environment and sense of place (Tipa, 2009). Streams and rivers in New Zealand have been degraded as a result of what many Māori perceive as inappropriate use and development (Tipa et al., 2009). There is a long history of Māori using and utilising river catchments for cultural and spiritual sustenance, stemming from a deep understanding of the river and the forces that surround it (Tipa, 2009). In Aotearoa New Zealand, almost all water management methods are based on quantitative data that focuses on physical, chemical and biological criteria (measureable data) as opposed to human values (Tipa, 2009). By ignoring the human element of environmental management, specifically, the connection that people feel with the environment, there is the potential to exclude large 
amounts of knowledge that can have a significant positive impact on environmental management.

\subsubsection{The boundary between Indigenous knowledge and Western science}

Indigenous knowledge and Western science have often been represented as two separate systems of knowledge, which Briggs (2005) describes as being characterised by a divide born out of two different world views. As a result of this perceived divide, Indigenous knowledge and Western science have been treated as discrete entities. Western science is perceived to be part of a modern era of knowledge and a wider notion of 'modernity'. Conversely, Indigenous knowledge is perceived to be part of a residual, traditional, and 'backwards' way of life (Briggs, 2005). In discussing the Indigenous knowledge/Western science boundary, Briggs (2005) draws on evidence from the study of development; noting how some forms of scientific processes have relied exclusively on one knowledge system from the West, and this system has dictated the marginalisation of non-Western systems.

Briggs (2005) suggests that the perceived separation between Indigenous knowledge and Western science arises because of a contextual/universal divide in thinking. Western science seeks knowledge of a general nature that is not context-related, and Briggs (2005) argues that research through Indigenous knowledge is produced in tight relationships within cultural and environmental contexts. In order for Indigenous knowledge to act alongside (or replace) the established Western science, Indigenous knowledge must first be viewed as a complement to, rather than a competitor of, Western science in the eyes of the proponents of Western science (Howitt \& SuchetPearson, 2006a).

Briggs (2005) highlights that a key issue to the acceptance and inclusion of Indigenous knowledge in the current Western scientific environment is 'power' and 'authority'. Power and authority are key issues because if actors accept that Indigenous knowledge 
is equally legitimate to Western science, the authority and power of the actors within Western science becomes seriously threatened (Cochran et al., 2008). Western science, and the authority that it holds within many environmental management systems (including Aotearoa New Zealand's), is seen as an instrument of power and is very unlikely to be ceded easily by experts for another system (e.g. mātaugranga Māori (Māori knowledge)). As Coombes (2007) notes in an analysis of Māori involvement of the Morere Scenic Reserve, Indigenous authority is restricted by the state. Indigenous authority is only acknowledged where it becomes convenient for conservation in the eyes of the state. The struggle facing the inclusion and implementation of Indigenous knowledge as part of environmental management is that, in order to be legitimised in the main stream, the dominance of current strategies based on Western science are challenged (Briggs, 2005; Davis, 2005; Stirling, 2014). Incumbent Western experts may even attempt to actively discourage Indigenous knowledge as a viable point of view for environmental management in order to keep their authority and power.

Briggs (2005) also discusses how Western science has maintained its power through the construction of a 'crisis narrative'. Briggs (2005) explains that for much of the colonial period, Indigenous knowledge was represented as a villain in the environmental management setting with Western science the hero or saviour. Such crisis narratives are used to sustain the position of the expert and the dominance of Western science in the environmental management setting through vilifying Indigenous knowledge and its proponents (Davis, 2005). Such a narrative is just one of the many processes through which Western science has been and continues to reject Indigenous knowledge in the environmental management setting.

It is interesting to note that when Indigenous knowledge is recognised within environmental management systems, overall managerial control is frequently still maintained by experts schooled in Western science (Leeuw et al., 2012; Nadasdy, 2005). Understanding how power, authority, and the systems that keep such processes in place, has become central to understanding the Western science/Indigenous knowledge 
boundary in an environmental management setting. Actors in this sphere have, and must continue, to be extremely conscious of the dynamics of power and positionality in reference to the production of knowledge (Leeuw et al., 2012). By acknowledging and accounting for the existence of power and authority at the boundary between Indigenous knowledge and Western science we can start to put in processes where Indigenous knowledge can play a bigger and more important role in environmental management.

\subsection{The politics of Māori environmental management}

Māori have a close and interdependent relationship with the environment (Harmsworth et al., 2016; Smith, 2005). Conversely Western views of the environment have tended to revolve around an idea of a binary relationship between nature and humans (Gibbs, 2010; Howitt \& Suchet-Pearson, 2006a). The Western view of the environment, and the values associated with it, tend to be in stark contrast to that of Māori culture. In recent decades there has been a Māori cultural renaissance in Aotearoa New Zealand (Smith, 2005). Such a cultural renaissance extends into the environmental management sphere where Māori have been able to assert their beliefs, customs and values as part of environmental management projects, both independently and in collaboration with other groups.

\subsubsection{Māori beliefs, customs and values}

Māori beliefs, custom and values are a result of a combination of cosmology, mythology, religion, geography and anthropology (Cunningham, 2000; Harmsworth et al., 2016). From a Māori perspective, the origins of the world are understood through a series of genealogical connections that go back numerous generations to the beginning of time (Harmsworth et al., 2016). This genealogical sequence is referred to as whakapapa, which places human beings as part of the environment, connected to all the other flora, fauna and natural resources in the world (Harmsworth \& Roskruge, 2014; Klein, 2000). A continuously evolving understanding of the environment provides the foundation for the Māori worldview, and encompasses all aspects of Māori knowledge, which was 
historically retained, organised and communicated orally rather than in written form (Tipa, 2009). Like all knowledge systems, mātauranga Māori has changed but remains distinguishable from Western science in several key ways including how Māori perceive the environment. Broadly, a Māori-based perception of the environment is that it extends beyond the physical and encompasses all the dimensions of environmental reality (Tipa, 2009). Tipa (2009) summaries the Māori values, beliefs and practices relating to freshwater to include kaitiakitanga (guardianship), whakapapa (genealogy), atua (god), mauri (life force) and wairua (spirit), mahinga kia (food-gathering place), rangatiratanga (chieftainship), and whanaungatanga (relationships).

Historically, Māori survival was dependant on their knowledge and understanding of the environment, and the sustainable gathering and management of resources (McGlone \& Wilmshurst, 1999). Kaitiaki is a Māori word derived from the verb "tiaki" (to guard; to protect) - with "kai" denoting the actor (Roberts et al., 1995). Thus, kaitiaki can be translated as a guardian, and kaitiakitanga the act of guardianship (although it is important to note that translations can never be complete in communicating the complexity of ideas). The idea of kaitiakitanga is central to a Māori view of the environment. It is important to note that kaitiakitanga involves not only the physical environment, but extends into social dimensions (Kawharu, 2000; Roberts et al., 1995). The concept of kaitiakitanga, and the types of management it produces, are born out of a necessity to look after the environment in such a way that it continues to provide natural resources for the local community (Kawharu, 2000). It is important to be aware of such Māori environmental concepts or values, as these can influence Māori environmental management decision making. Harmsworth and Roskruge (2014) define Māori environmental values as instruments through which Māori not only make sense of the environment, but also the way in which it is experienced and interpreted. Māori values flow into Māori worldviews and provide conceptual principles for Māori to use in everyday life, and often to inform ethics and principles (Tipa, 2009). Such Māori values, and related worldviews, are central to how Māori interact with the environment and can govern Māori environmental responsibilities and relationships. 


\subsubsection{Colonialism and environmental management}

Colonisation in Aotearoa New Zealand happens in multiple interlinked ways. These interlinked processes include the establishment of the armed constabulary (Wink, 2005), violent evictions of Māori from the land (Tapsell, 2002), and the ongoing prioritisation of Eurocentric norms and institutions over te ao Māori (the Māori world). The imposition of European worldviews on Māori represents a prioritisation of an instrumentalist approach towards the environment and its resources (Burton \& Cocklin, 1996). Such an approach is linked to capitalism and where a high degree of value is placed on the ability of a resource to produce economic growth.

The dominance of colonisation is never complete, rather colonisation continually excludes other discourses and ideas. Such other discourses, like Māori worldviews, are always circulating but they remain undervalued. Mãori have carried on managing the environment according to their worldviews after the signing of the Treaty of Waitangi, but in certain places Māori practices were suppressed, and over time the legislative framework has reinforced a Eurocentric worldview. However, the legislative framework around environmental management has evolved over the last few decades to promote and protect nature for its intrinsic value as well as for its potential economic benefit (Gladwin et al., 1995; Igoe \& Brockington, 2016). Nonetheless, Māori environmental management has been impacted both by colonialism and later Western models that place an economic value on the environment. There has been limited formal political avenues, such as regional/city councils or catchment committees, in which Māori have been able to express their own environmental management values.

It is important here to mention the Resource Management Act (1991) which has been praised by many for including Māori (see Beverley, 1998; Jollands \& Harmsworth, 2007), and criticised by others for not going far enough to include Māori worldviews (Joseph \& Bennion, 2003; Painter \& Memon, 2008). As will be discussed below, almost all sections of society and culture in Aotearoa New Zealand cannot escape or overcome the weight of the country's colonial history. Environmental management is not an exception, and 
the processes that exist in, and people who function within this sphere are unlikely to avoid wholly the negative influences of institutionalised colonialism. Environmental decision-making processes are dominated by Western approaches that end up separating nature and society, which devalues the Indigenous emphasis on the importance of interdependence between people and the environment (Panelli et al., 2009).

\subsubsection{Post-colonial environmental management}

Through the process of colonial exclusion, a large part of Māori environmental management has for the last 140 years occurred outside the governmental environmental framework (Memon \& Kirk, 2012). However, there have been recent efforts to include Māori knowledge and perspectives of the environment across many levels of environmental management in Aotearoa New Zealand. Māori advocacy since the 1970s has steadily increased the development of research for Māori and by Māori across multiple sectors, including environmental management (Prussing \& Newbury, 2016). Alongside Māori advocacy, the rejection of neoliberal trends by the wider environmental management community has also promoted alternative forms of environmental decision making. For Aotearoa New Zealand such alternate forms of environmental management include Māori perspectives, values and the development of cultural health indexes for freshwater, alongside the integration of Indigenous knowledge in decision making through co-management (see Coombes, 2007; Harmsworth \& Roskruge, 2014; Jollands \& Harmsworth, 2007).

Co-management is the sharing of power between government and local communities, in this case Māori iwi and hapū (Māori subtribe) (Berkes, 2009). Within co-management the Māori concept of kaitiakitanga has emerged as a key vehicle for achieving Māori governance in environmental management (Forster, 2014). The neoliberal ideas that promote the privatisation and corporatisation of the environment limits the scope of state governance in environmental management. These neoliberal ideas relating to the environment have been challenged by many Māori. In particular, ideological challenges have resulted from the undermining of collective rights, the undercutting of support for 
culturally diverse world views (including Māori views), and the lack of recognition for the ways in which market-driven approaches themselves produce and sustain environmental inequalities (Prussing \& Newbury, 2016).

Recently, there have been an increasing number of environmental co-management programmes that include Māori groups, or at the very least in some way ensure Māori environmental knowledge and perspectives are applied. Management groups like the Waikato River Authority (Kanwar, 2014), Te Awa Tupua settlement, and other recent comanagement initiatives including a report on Cultural Health Index for streams (Townsend et al., 2004), and the Motueka Integrated River Catchment Scheme (Fenemor et al., 2011), show there is an increasing number of natural resource comanagement schemes in Aotearoa New Zealand. Coombes et al. (2011) highlight that the failure to recognise and incorporate plural worldviews in environmental management can explain why in the past negotiations between Indigenous and nonIndigenous parties fail to include key concerns about land ownership.

Co-management has often been touted as the solution to the non-inclusion of Indigenous rights and values, yet co-management can sometimes serve as the basis on which racist or "biocentric" agendas of non-Indigenous parties are enabled (Kepe, 2008). Such biocentric agendas are able to play out in co-management through the institutionalised power structures inherent in environmental management. By framing the environmental as something to be managed is not necessarily in keeping with Indigenous ideals and values, and such misrepresentation of co-management leads to the Indigenous priorities being disregarded (Coombes et al., 2011). Importantly, Coombes et al. (2011) highlight that worldview differences can result in competing ideas in co-management scenarios, which will become more pronounced when environmental crises gain more mainstream attention.

While the Whaitua Implementation Programme isn't formally considered as a comanagement process, it still handles Indigenous knowledge in a co-management 
context and is subject to processes that disregard Indigenous values. Co-management is a culturally complex political process (Nadasdy, 2005). Ignorance of the political nature of the process by managers, stems from one of the assumptions underlying the discourse of co-management: that the value of Indigenous knowledge is treated as an addition to be incorporated into environmental management (Nadasdy, 2005). Nadasdy (2005) explains that it is this assumption that results in Indigenous knowledge becoming a 'technical' rather than political or ethical problem.

\subsubsection{Aotearoa New Zealand as a bicultural nation}

In order to appreciate the processes of environmental management politics, we first must understand the cultural dichotomy of Aotearoa New Zealand in which environmental management takes place. Bell (2006) argues that since the 1980s the overwhelming impression of Aotearoa New Zealand is that it is made up of two founding people, Māori and European. Born out of the movement that started in the 1970s for greater Māori political aspirations and self-determination, the state developed the idea of a nation founded by two cultures, otherwise known as biculturalism (Bell, 2006). However, Bell (2006) argues that while the idea of biculturalism goes some way to fulfilling Māori self-determination, biculturalism actually works to keep the two peoples apart. Such a cultural gap is achieved through biculturalism's oversight of the colonial history of Māori and Europeans (Said, 1993). With the development of biculturalism, the Treaty of Waitangi has been elevated to the status of Aotearoa New Zealand's 'founding document' (Byrnes, 2004, p. 8). Such recognition of the Treaty has served to provide a limited avenue for Māori to redress the political and economic injustices of colonialism (Bell, 2006). Bell (2006) argues that biculturalism emphasises the difference between Māori and Europeans and draws a sharp line between the two cultures. What is lost by accepting biculturalism is an understanding of how Māori and non-Māori cultures interact, which Said (1993, p. 36) refers to as "entanglements". Ignoring these so-called entanglements between the two cultures detracts from the study of the complexities of the connections and oppositions between Māori and Europeans (Said, 1993). Bell (2006) argues that bicultural polices since the 1980s have provided the opportunity for Māori cultural expression, yet the "rhetoric of biculturalism" as it has played out asserts the 
unequal and separateness of Māori and European cultures in ways which facilitates the forgetting of colonial histories and its aftermath.

The forgetting of colonial histories by Europeans has the aim of avoiding contention around their dominance of Aotearoa New Zealand society (Bell, 2006; Berg \& Kearns, 1996). Forgetting, from a Māori perspective, breaks with the traumas of colonisation and furthers Māori desire for self-determination. While 'forgetting' is attractive for both cultures it becomes paradoxically problematic for developments beyond colonial relations, which is what biculturalism itself stands for. For Europeans in particular, the attention to separateness allows for the colonial history that has dominated Māori to be ignored. It is through the advancement of biculturalism, and the 'forgetting' of colonial histories, that the continued cultural and political dominance by Europeans is enabled in Aotearoa New Zealand.

However the recent rehabilitation of the Treaty of Waitangi symbolises a renewed partnership between Māori and non-Māori peoples that challenges the polices and nationalist tendencies of biculturalism. Aotearoa New Zealand is understood to have two equally valid and legal cultures - Māori and European (Bell, 2006). In reality such equality is not the case. Mãori remain disadvantaged throughout a wide range of economic and societal indicators that demonstrates the recognition of the Treaty has yet to result in substantial equality. Within the politics surrounding biculturalism, motivation for contributing to the discussion of partnerships in environment management goes beyond the medium in which they might be expressed. Coombes et al. (2011) note that Indigenous motivations in environmental management are linked to the wider aspirations of recognition, reclamation of sovereignty, and resistance to colonial processes, i.e., conflict in the environmental management setting is not merely 'a resource conflict'. Conflict in this setting transects boundaries, and has far-reaching and significant implications for Māori. 


\section{Chapter Three}

\section{Methodology}

The research for this thesis involved a qualitative study involving members of the Ruamāhanga Whaitua Committee. The Ruamāhanga Whaitua Committee is part of the Greater Wellington Regional Council's Whaitua Implementation Programme, and is tasked with setting up guidelines that will be incorporated within the Proposed Natural Resource Plan for the Wellington Region. The research framework of this study is based on critical theory, with a post-colonial methodological approach. The research involved semi-structured interviews with members of the Ruamāhanga Whaitua Committee including iwi representatives from Rangitāne o Wairarapa and Ngāti Kahungunu ki Wairarapa. A critical discourse analysis was used to analyse the resulting data. This chapter outlines the research approach and related methods in more detail.

\subsection{Critical theory}

The ontology (the nature of what exists in the eyes of the researcher) and epistemology (the information that the researcher considers to constitute knowledge) of critical theory revolves around the idea that reality has been shaped over time by social, cultural, political and economic pressures (Rexhepi \& Torres, 2011). Critical theory ontology seeks to understand multiple realities, and while doing so, acknowledge the idea that knowledge (our understanding of reality) reflects prior experience and wider societal structures and norms (Morrow \& Brown, 1994). Structural inequalities are present within background societal function and operation (Winchester \& White, 1988). Systematic structural inequalities produce marginalisation and the experiences of marginalised groups are of central importance to a critical theory approach. A critical theory approach is important to any study that investigates the incorporation of values in environmental decision making because of the high level of societal influence present. The Ruamāhanga Whaitua Committee is set in system that has such high levels of social 
influence. Society and the structures of marginalisation that it imposes on environmental decision making are not exclusive to the Ruamāhanga Whaitua Committee. All forms of decision making are subject to power inequalities and are present throughout environmental decision making in Aotearoa New Zealand. A critical theory approach lends itself well to a study involving Māori in Aotearoa New Zealand because Māori have deep social, cultural, political and economic pressures associated with their interaction with freshwater. Similarly, there are colonial powers present in Aotearoa New Zealand society that have, and continue to, shape environmental decision making that works against Māori contributions to environmental management. Nonetheless, it is important to highlight that Māori have exercised a huge amount of agency in resisting and reshaping these structures of marginalisation.

\subsubsection{Post-colonialism}

I have chosen to take a post-colonial methodological approach due to the cross-culture nature of this research. Post-colonial methodology sits within critical theory ontology as it highlights knowledge outside of the perceived main stream. A post-colonial approach focuses on the stories and experiences of people who have a history of being marginalised (Hay, 2010; Parsons \& Harding, 2011). Māori, since the arrival of Europeans to Aotearoa New Zealand have suffered politically, economically and culturally as a result of colonial processes (Coombes, 2007; Smith, 2005). The acknowledgement of the presence of colonialism and rejection of such colonial pressures is part of the postcolonial methodology and reinforces the critical theory approach (Parsons \& Harding, 2011). Post-colonial qualitative research emphasises the need to understand and reject the power differential that has been present in research relationships as a product of colonial histories.

Acknowledging and working against such deficit structures is referred to as anti-deficit thinking (Menchaca, 1997; Valencia \& Solórzano, 1997). This kind of anti-deficit thinking is present in much of Aotearoa New Zealand's education literature, but not often included in the environmental management literature. Bishop et al. (2009) highlight in 
their paper on addressing the educational disparities facing Māori students in Aotearoa New Zealand, that there are some key challenges facing education in Aotearoa New Zealand. Such challenges include the disparities between the descendants of European colonisers and Māori in social, economic and political settings (Bishop et al., 2009). Bishop et al. (2009) note that despite the decades of reform aimed at addressing educational disparities, for the majority of Māori students there has been little shift in measured disparities. Bishop et al. (2009) further identifies that what stops the significant advances in reduction of the education disparities is that the current policies and practices have been developed within a framework of neo/colonialism, and resultantly are attuned to the interests of the single Western culture. The maintenance of such policies and practices in the mainstream is based upon, and are created within, the context of racism (Scheurich \& Young, 1997). That is to say, Scheurich and Young (1997) believe that racism is embedded in the fundamental building blocks of the principles of the dominant culture within Aotearoa New Zealand, and produces a Eurocentric structure that reinforces itself. Parallels in the understanding of deficit structures can be made between education and environmental management. Policies and practices around environmental management in Aotearoa New Zealand would also reflect and reinforce the social history and the powerful controlling position of that racial group (Europeans), and produce an environmental decision-making structure that excludes the view points and information from other races and their cultures.

Howitt and Stevens (2010) explain that researchers undertaking a post-colonial analysis must reject the attitudes, assumptions, purposes and methodologies of established colonial research. Colonial research reinforces the domination and exploitation of Indigenous values through the differential power balance innate within the research relationships with marginalised groups, including the dismissal of their rights and knowledge, and the use of intrusive and non-participatory methodologies. Such Western research functions in a way which allows Western researchers to categorise and classify societies, condensing complex ideas of other societies, enabling a model of comparison and the ranking of other societies (Hall, 1992). Such procedures, as identified by Hall (1992), are the processes by which Indigenous people and their 
cultures were and are moulded to fit the Western system of knowledge and status quo. Howitt and Stevens (2010) identify post-colonial research is born out of a response and rejection of such colonial research with an intention to support marginalised groups in self-determination. This research utilises post-colonial research methods in the research processes by placing value on the rights, knowledge, perspectives of participants of the research who are part of marginalised groups or historically marginalised groups.

\subsubsection{Kaupapa Māori}

In taking a post-colonial approach to this research it is important to highlight the processes that have already been established within research that reject colonial themes. Kaupapa Mãori is one of these such processes. It is also important to acknowledge and consider Kaupapa Māori as this research involves tangata whenua. Kaupapa Māori refers to research theories and methodologies that centre on Māori language, culture and knowledge (Smith, 2005). There has been much debate within literature addressing Kaupapa Māori around the involvement of non-Māori in Māorirelated research. One of the stronger themes within the literature is that as part of any Kaupapa Māori research there cannot be non-Māori involvement, a point highlighted by Jones (2012, p. 101):

Kaupapa Māori provides a set of rules defining a philosophical and methodological research space strategically formed by Māori, for Māori purposes; Pākehā [Māori word for persons of European or other foreign decent] - whose position of power and whose destructive and controlling research 'on' Māori forced such a response into being - are necessarily outside its development.

Jones (2012) notes that there is an emphasis that Kaupapa Māori is Māori owned and controlled and that being Māori, and identifying as Māori, are critical elements of Kaupapa Māori research. Such ideas around Kaupapa Māori research suggest that by definition, non-Māori people cannot legitimately be involved in Kaupapa Māori research. 
Thus this study does not take a Kaupapa Māori approach because I am a researcher of European descent. The study will, however, focus on how Māori and non-Māori worldviews and knowledge interact within environmental management. This study aims to focus on how the particular values of two iwi are articulated and advocated for within a system that has marginalised Māori values and privileged non-Māori worldviews. In doing so it is important to recognise the distinction between Māori and non-Māori in a research context, and that such a distinction should not be ignored (Jones, 2012). I have chosen this focus for my research because the politics of how Māori are able to interact in environmental management interest me, and I feel that more can be done to include Māori and Māori values in environmental decision making.

Through her experience as a non-Māori researcher involving Māori communities, Jones (2012) found that the distinction between Māori and non-Māori is necessary for respectful and productive research to take place, and ignoring it does not work. For non-Māori to be able to engage respectfully and productively with research in a Māori sphere, researchers must be willing to engage with Māori and foster and respect any researcher-Māori relationship. For this research I first sought to engage with the iwi who were involved with the Ruamāhanga Whaitua Committee and make sure they were comfortable with me undertaking the research. More information about relationship building with these iwi is included below.

\subsubsection{Researcher positionality}

Davies and Gannon (2005) identify that researchers filter information through a personal lens that is situated in socio-political and historical moments. Researchers are shaped by their economic, societal and historical backgrounds as well as their current situations. Milner (2007) notes that there are many dangers (perceived or otherwise) that can present themselves if researchers do not account for their own, and other cultural systems of knowing, understanding and experiencing the world. Researcher 
awareness of such positionality in a research context, alongside the reflection of any positionality bias, is a critical part of carrying out fair and transparent research and for such research to be academically rigorous (Cheek, 2008; Waitt, 2010).

As a researcher I understand that my own positionality can influence how I conduct research, and how I analyse and interpret information that is presented to me. I will highlight a few factors in my life that influence my positionality, with specific relation to this research. Since an early age, I have taken a keen interest in the environment due to living in a way that brought me into contact with many different ecosystems through a number of outdoor activities (e.g., surfing, camping). The way I have come to understand the environment is solely through a Western science background, initially through my father, who is a European-trained marine biologist, and later through secondary and tertiary education in Aotearoa New Zealand where teachings are mostly rooted in Western science theory and methods. I have come to hold strong ideals around how people should treat the environment in a way that means it would be preserved for future generations. Such ideals relate more to the way I have been brought up rather than the Western educational system. I have had previous experience working in a cross-cultural setting overseas in the Autonomous Region of Bougainville (an island nation in the Pacific Ocean). This time spent immersed in a different culture and language, cultivated an interest in how different worldviews meet and interact, and I took away many lessons that I believe have a degree of transferability to the research context.

It is important to highlight that I am of European descent and not accustomed to Māori protocol because I have had a relatively small amount of engagement with Māori culture. I am very aware of my positionality within a Māori setting as a researcher of non-Māori descent, and understand that certain Indigenous knowledge (that could be useful to the research) may not be available to me. With my positionality in mind, there is a potential for this research to be interpreted through the knowledge I have constructed. Such constructed knowledge is linked to my European descent and Western science educational background. 
The practice of reflectiveness as part of the research agenda encourages the researcher to reflect upon their own position as well that of the participant(s), and to acknowledge and use these reflections to direct the research process (Kitchin \& Tate, 2000). Such reflections include acknowledging that I am not an expert in Māori culture nor Māori environmental management, and thus this process required seeking knowledge from local iwi involved in the Ruamāhanga Whaitua Committee. Kobayashi (2003) notes that self-reflective scholars can be concerned about the potential for perpetuating the forms of social marginalisation that form the very basis of our research and social interactions. Interestingly, Kobayashi (2003) notes that an activist stance flows from the selfreflective stance that scholars aim to take. As such, I conceived of this research work in part to aid, in any possible way, the promotion and discussion of Māori values in an environmental management context.

Rapley (2001) concluded that any data obtained from an interview is highly dependent on the specific social interaction that occurs between the interviewer and interviewee. Any data gained in such a way is contingent on the specific local interaction and is just one possible version that could emerge. With such ideas in mind, I was aware of my positionality and how it might have shaped the interview process and subsequent analysis. I aimed to conduct research that provided fair and thorough analysis of the topic by acknowledging my positionality as a researcher. Acknowledgement of my positionality has made me, as a researcher, aware of the influences (like Western values) that may negatively influence the research such as learnt views around the environment and people. Being aware of such negative influences means that I made a conscious effort to make sure the research is not effected by my positionality in cases where it can be controlled or mitigated.

\subsection{Research methods}

This research involved five semi-structured interviews with the members of the Ruamāhanga Whaitua Committee. I used a critical discourse analysis to analyse data 
from the interviews, with particular attention to the incorporation and implementation of Māori values. Such qualitative research methods are the best tool for uncovering depth and complexity, and how meaning is made and contested, with reference to explaining human environments and human experiences (Winchester \& Rofe, 2010).

\subsubsection{Interview methods}

Utilising interviews as a form of qualitative data collection has a number of benefits. As Dunn (2010) explains, one of these benefits is that interviews can act as an excellent method for drawing out opinions and experiences from people. Interviews can be structured in a number of ways, including a semi-structured approach. Semi-structured interviews employ an interview guide but do not restrict the interviewer to specific questions; rather they enable flexibility when questioning a participant (Dunn, 2010).

My research methods consisted of individual semi-structured interviews. The five interview participants consisted of the two iwi representatives plus three other Committee members recruited with the help of the acting chair of the Ruamāhanga Whaitua Committee. The interviews were split into two phases. In the first phase of the interviews I interviewed the two iwi members of the Ruamāhanga Whaitua Committee with the aim of defining the Māori environmental values that related to the Whaitua Implementation Programme of the Ruamāhanga catchment. The phase one interviews also incorporated a similar line of questioning as the phase two interviews. These phase one interviews were conducted after I had initially approached the two separate iwi to discuss the scope of the research. I met separately with individuals from both iwi to present the general aim and approach of the research, to develop a relationship with iwi committee members prior to interviewing them and to invite their input into shaping the project. I made sure that prior to any interviews taking place, both Ngāti Kahungunu ki Wairarapa and Rangitāne o Wairarapa were comfortable and happy with my research taking place. It was important for the research to be guided by the phase one interviews with the iwi representatives. The values that were discussed with the iwi members of the committee was an important consideration for the research due to my positionality. 
These phase one interviews were conducted with the use of an interview guide (Appendix 1).

The information that was gathered from the first phase of interviews informed the line of questioning for the second phase of interviews with members of the Ruamāhanga Whaitua Committee who were not iwi representatives (Appendix 2). I had intended to interview more members of the Committee, however I was unable to recruit any other participants within the timeline. There are a number reasons why this may have been the case, including the political nature of my topic, and the fact that Committee members were already volunteering their time to their Committee work so may have been time poor at the time of my research. Despite to the small number of interviews, a qualitative approach I adopted meant that there was enough information shared with me by participants to produce interesting and useful findings.

The interview guides for the second phase of the research were based on the research questions for the thesis. The research questions for this research were developed after having discussed with iwi the nature of the project, but before the interviews took place. As such there is a level of accountability that this research has to Rangitāne o Wairarapa and Ngāti Kahungunu ki Wairarapa in answering the research questions adequately. These questions referred to the identification, inclusion and implementation of Māori values. Questions in both phases of the interviews revolved around the participants' background, Māori environmental values, the incorporation and implementation of Māori values in the Whaitua Implementation Programme, as well as any changes they thought should be made to the Whaitua Implementation Programme processes. I employed the use of open-ended questions that allowed participants to express ideas from their own experiences and backgrounds. Interviews were held at a variety of locations dependant on where the participant felt most comfortable. 
Rapley (2001) discusses how it is often in the nature of the researcher when interviewing not be neutral during interviews. While it can be important for the interviewer to limit their opinion on a topic during an interview in order to give the interviewee the possibility of a wide scope of answers, full neutrality is difficult to achieve (Kobayashi, 2001; Rapley, 2001). Kobayashi (2001) highlights that it is important for the interviewer to sometimes voice an opinion on a topic in order to create and establish a rapport with the interviewee that promotes in-depth conversation. Such conversation is a product of both the interviewer's and interviewee's opinion which is informed, to a degree, by their positionality. The members of the committee who participated in the interviews were from a variety of backgrounds and were employed in a diverse range of practices. As noted above, each of the participants' positionality will have affected each interview in different ways. Each interview was different in the way my positionality interacted with that of the participant. In some cases, it became clear that I needed to outline my position around certain topics (including environmental management and Māori values) in order for participants to feel comfortable in discussing sometimes intimate perspectives. However, for some interviews I remained neutral in my position in order for the participant to not feel they were likely to present thoughts counter to the research themes. In identifying myself as a student from the Victoria University of Wellington, it was my perception that all participants felt more conformable sharing information as part of the study, as it was clear the research was independent from the Greater Wellington Regional Council. However, some participants were extremely cautious around the views they expressed in the interview, as they were mindful of the eventual public nature of the findings of the study. Participants did not verbally communicate they felt they could not fully express certain levels of criticism (towards the Greater Wellington Regional Council and/or the Whaitua Implementation Plan process), but declined to answer some questions. However, it is my opinion that the general reception of the study by participants was positive, and all participants recognised that the Whaitua Implementation Plan was not a perfect processes, and welcomed an independent analytical element. 
Prior to the beginning of the research, approval from the Human Ethics Committee of Victoria University of Wellington was sought and received (Appendix 3). Before any interviews were conducted, all interviewees were given an information sheet and consent form to sign (see Appendix 4, 5 and 6). Interviewees were reminded that they could stop the interview at any time, and remove themselves from the research at any time. The interviews were digitally recorded with participants consent. While the interview transcriptions remain confidential, there may be situations where individuals who are involved in the wider Whaitua Implementation Programme may be able to attribute certain responses to certain individuals. Even indirect participant identification can be problematic, and choosing to identify this in the information form given to participants has the potential to shape what participants choose to share. This thesis will be made fully available to members of the Ruamāhanga Whaitua Committee and wider organisations. It is my plan to produce a summarised version of the findings after the thesis has been completed in order for it to be accessible to a wider audience.

\subsubsection{Data analysis methods}

A discourse analysis was determined to be the best method to analyse the textual information from the interviews. I used a critical discourse analysis approach, which differs slightly from traditional discourse analysis in that it takes a more interdisciplinary approach (Wodak \& Meyer, 2009). Wodak and Meyer (2009) explain that critical discourse analysis puts less weight on the linguistic aspect of the discourse, but rather prefers to study the social phenomena which are complex and thus require a multidisciplinary approach. It is important to highlight that critical discourse analysis is not 'critical' in the negative sense, rather it aims to challenge assumptions that might be taken for granted. Social and political phenomena, which are the focus of the research, lend themselves well to any critical analysis as they should not be taken for granted. In short, critical discourse analysis aims to understand and demystify ideologies of people within society through the investigation of discourses, most usually written, spoken or visual data. 
A critical discourse analysis was used because the method aligns with the critical theory approach. In the tradition of critical theory, critical discourse analysis aims to shed light on discourses relating to aspects of societal disparities and inequalities (Wodak \& Meyer, 2009). Integral to critical theory, and thus critical discourse analysis, is the idea and recognition of the researcher's positionality as part of the research, which has already been discussed in this chapter. Critical discourse analysis acts as a sort of an umbrella of approaches for analysing discourses. While there is not one consistent critical discourse analysis methodology, there are some features which are common to most critical discourse analysis approaches.

Power plays an important part in critical discourse analysis. Researchers who use critical discourse analysis are interested in the ways social domination is replicated in discourses. Social domination is the abuse of power of one group over another group. How dominated groups may resist and refuse the abuse of power can also be evident in discourses. Power in critical discourse analysis is usually perceived as a systematic and constitutive characteristic of society (Wodak \& Meyer, 2009). That is, power is an organic product of the way society functions. This idea that power and society are intimately connected is drawn from philosopher Michel Foucault (Cheek, 2008; Potter, 2008). Cheek (2008) explains that Foucault considered that power results from sociohistorical processes, whereby knowledge underpins discourses. And as such knowledge can be used by proponents of that discourse to claim both authority of a setting and to exclude other alterative discourses (Cheek, 2008). Critical discourse analysis adopts this idea of power being a product of society and how it can be used to promote/exclude discourses from a setting. Wodak and Meyer (2009) make the point that while power is an important element for understanding any setting, it remains by and large, invisible. Thus, understanding how power manifests itself in society through discourses is a key part of critical discourse analysis.

There are a few issues that question the validity of critical discourse analysis. Weninger (2008) highlights one of the more prominent criticisms of critical discourse analysis. The criticism is that the analyser of the text has prior political and critical stances that are likely to be 'found' when analysing the texts. As addressed above, I have outlined my 
positionality as a researcher and the steps I have taken to make sure that my bias has the smallest possible impact on the research.

Once transcribed from audio format to text, the interviews with the participants were analysed. The five participants were randomly given letter assignments $A, B, C, D$ and $E$, in order to preserve personal anonymity. Analysis revolved around processes of power and these were revealed as different ideas or themes across the five texts. The analysis of the participants' accounts within each text were conducted manually (i.e., I identified them rather than using computer-based algorithms). Similar or corresponding accounts from the participants across the texts were grouped under loose themes relating to power manifestation. The four general working themes were the "Conversion of iwi values", "Historical hangover/histories", "Balance of power" and "Power struggles". These initial four themes evolved through the analysis processes and were reduced to three more clearly defined themes that are described in the following chapter. 


\section{Chapter Four}

\section{Results}

The purpose of this research was to try to ascertain and understand the level to which iwi values (as representative of Māori values) are included in the Ruamāhanga Whaitua Implementation Programme by the Ruamāhanga Whaitua Committee. This chapter presents the findings that emerged from the data gathered through the interviews, and subsequent analysis using the conceptual framework and methodology outlined in previous chapters.

Three clear themes emerged from the data analysis. These were: (i) the values that research participants attributed to the Ruamāhanga Whaitua, (ii) how different values were balanced by members of the Ruamāhanga Whaitua Committee, and how this was effected by the make-up of the committee and, (iii) the contrast with, and prioritisation of, Western values over Indigenous values because of the dominance of the numeric (Western) over the narrative (Indigenous) rhetoric by the Ruamāhanga Whaitua Committee.

\subsection{Ruamāhanga Whaitua Committee values}

Analysis of the interview transcripts indicated that there were a number of iwi values that Ruamāhanga Whaitua Committee members associated with the Ruamāhanga Whaitua. These values include the ways in which the iwi representative members of the committee connected to and valued the whaitua (both intrinsically and extrinsically), and what priorities they felt should best be represented in the Whaitua Implementation Programme. Given that this thesis is investigating how iwi freshwater values are treated in the Whaitua Committee setting, and that I am not from either of the two iwi and thus cannot determine what these values are, this section uses information from Participants $A$ and $B$ to lay the foundation for this findings chapter. The two iwi representatives are designated participants $A$ and $B$, and the non-iwi representatives $C, D$ and $E$. The results of the initial phase of interviews with iwi representatives are included in this section. 
The values discussed by all the participants covered a range of ideas; many of which were similar across all, or a number of interview participants, but some were unique to a single participant. The participants also noted that many non-Māori committee members shared the same values as Māori.

From the initial phase of the interviews participants $A$ and $B$ both noted a strong connection to the Ruamāhanga whaitua. Participant A highlighted their own connection to the river in stating "[the river] is so important to life. It's so important to go down [to the river]... and when it's looking so clean you know it's good to swim in [and be around]". Participant A also noted the fact that the wider community holds many of the same values and concerns around the state of the river. "[The public] are concerned with what's happening. You know you go and you just sit there [on the Ruamāhanga Whaitua Committee] and listen to what [the public] are saying, and they are dead right about what's happening with the low flow and the water". These initial interviews show that iwi representatives value the whaitua for the connection to life itself, as well as expressing that the whaitua has importance for the wider community.

Participants B, C and D noted the agreement of values between Māori and non-Māori committee members. Participant B emphasised the joint understanding Māori and nonMāori committee members have around river values by saying "It is not a struggle for [non-Māori committee members] to understand Māori values". Participant B expanded to say that when committee members were asked to identify which values spoke strongest to them "most of them chose kaitiaki and [the committee members] said they care about the water, and they want to see water doing well". Participant C also noted "I don't think there is too much disagreement around values [within the committee]". Participant $D$ acknowledged that while some values were not universally understood within the committee to begin with, "[non-Māori committee members] to their credit have come on board and I know some of them haven't had much involvement with Māori or kaupapa before". 
While analysis of the interview responses indicated that the values that have been discussed within the committee are generally almost always agreed upon, it is important to note that such discussion may not cover all associated values of committee members. Participants A, B, D and E expressed views about the lack of discussion around Māori values on the committee. Participant B noted that the "framing of [values] is quite different" but that initially there was good reception to Māori values however the discussion of these values tailed off through the process. Participant $D$ noted that values not related to Māori that are more "based in science" have a big push behind them by certain groups on the committee. Participant E stated that they felt that "[the committee] haven't talked enough about Māori values... we've talked about all sorts of values, but not explicitly Māori values".

\subsection{The prioritisation of values and committee make-up}

One of the more significant themes to be identified by the analysis was the idea of value prioritisation, and the resultant balancing of values in committee discussion. As noted above, interview participants generally agreed on a number of Māori values they associate with the Ruamāhanga Whaitua Committee. However, participants communicated there is some disagreement among Committee members around the weighing-up of what values are more important than others. Almost all the interview participants (four of five) indicated that they thought that the relative weight placed on the values was related to the make-up of the committee. In particular, the ability of nonMāori representative members to 'bulldoze' some values in favour of others, seems to be a product of the balance of the committee members, and to what part or sector of society they associate.

Participant C noted that they “don't think there's too much disagreement around the values [of the Ruamāhanga Whaitua Committee], where the discussion of values becomes more complex is around the balancing of values". Participant C continued "so 
if you've got values around economics and farming practices, against swimming ... water quality in general, there is going to be some compromise. The degree of compromise I think is the challenge of the committee". Participant C expanded to say that "it's not that there is not alignment in values and principles [on the committee], it's just some of the understanding is a wee bit different". That is, research Participant C is conveying, in their opinion, Ruamāhanga Whaitua Committee members agree on almost all values and principles, but there is no unanimous agreement on the "understanding" of which values or principles should be incorporated into the Whaitua Implementation Programme.

Participant A highlights that the make-up of the committee seems to affect the weight different values are given. Participant A's understanding is that such disagreement is most likely because "a lot of people are going to be hurt by the changes if we [the Ruamāhanga Whaitua Committee] do bring them into force", and that the majority of the committee is made up of farmers. Such changes could include tighter restrictions on water use and the amount of water than can be taken for agricultural purposes within the Ruamāhanga whaitua. Participant $D$ also noted that the balancing of values could have something to do with number of iwi representatives on the committee:

"I think there's more room to include Māori. When you look at the [Whaitua Implementation Programme's] terms of reference it talks about 'partnership with Māori', that they are partners in this process and therefore I would have thought there would be more Māori faces at the table."

Participant B followed on from this idea of partnership. From Participant B's point of view, iwi, through the Treaty, are in a partnership with the government to resolve issues, whereas "in the Whaitua Committee, [Māori are] more stakeholders than partners". Participant B believes that "Māori are definitely not partners on the voice side, [Māori] were more stakeholder at the table". Participant B makes specific mention of the number of iwi representatives in the Ruamāhanga Whaitua Committee, and that in being considered only as stakeholders reduces the number of iwi representatives to two of 14 members, rather than in a partner situation where iwi would represent half of the 
committee numbers. Participant $\mathrm{C}$ also explained that one of the challenges facing the Ruamāhanga Whaitua Committee is the make-up of the committee, and the effect it can have on the balance of values that are incorporated in the Whaitua Implementation Programme. Participant C states that one has "got to be a wee bit careful about your membership and one of the challenges around catchment communities [is] that it's not necessarily about sector representation, but it is something around dominance and people bulldozing their values".

Participant A identifies what they thought to be a contributing factor to the uneven balancing of values in that "at the end of the day the [previous] government will always be on the farmers' side". Participant A suggested that such an agenda at a high-level trickles down and adds weight to values that are presented by certain members of the committee. Participant D was also aware that community groups can be influenced by external policies "I hear all the time [in the Ruamāhanga Whaitua Committee] 'economics, economics' and whatever the section is in the RMA. Well hang on, that's only part of what's important, but it's not the biggest part". Participant D explained that one of the bigger parts of the RMA is practicing "environmental stewardship", not "economics in terms of business as usual". Participant E also noted that having two iwi representatives on a committee of 14 "possibly [doesn't]" give iwi adequate representation.

\subsection{Indigenous or Western setting}

The final theme to emerge from the analysis of the interview data is the importance of the cultural setting in which values are discussed. As shown above, participants agreed on a number of values they associate with the Ruamāhanga Whaitua Committee, but noted that the relative weight attached to these values and the balancing of these values could be dependent upon the committee make-up. Not only was the level of importance each value should be given not unanimous, but the setting or 'language' in which that value should be discussed was a point of contention between members of the committee. Participants explained that during committee meetings, values tended to be 
assigned or viewed as measurable or non-measurable. Participants explained that understanding values as non-measurable or non-quantifiable was associated with Māori perspectives, while understanding values as measurable or quantifiable was associated to non-Māori or Western perspectives. That is, Indigenous values were viewed a nonmeasurable and Western values as measurable. With value discussion occurring in a binary manner, either being measurable or non-measurable, participants noted conflict between the two sets of perspectives. All participants recognised the distinction between the two sets of perspectives and drew particular attention to it during the interviews. Most participants agreed that the junction at which Indigenous and Western met in the Ruamāhanga Whaitua Committee discussions could be problematic for the inclusion of iwi values in committee discussions.

Participant A explained that the values they associated with the Ruamāhanga Whaitua Committee were much more connected to a holistic understanding of the environment: "we've always had something to do with water ... even going back hundreds of years, water was one of our main sources whether it would be food or travel" and that "when we were kids we used to go eeling on the weekends down at the river". For Participant A, not only was the history they felt with the river expressed in a narrative way, the values which they attributed to the river could not be expressed in a "measureable" way. That is, their values existed outside of the established Western science setting.

Participant B believed that the measureable system in which water management in Aotearoa New Zealand operates is affecting Māori - "the flood protection guys are building for a one in a 100-year event, we get 99 years and 51 weeks living with what they're doing". Participant B also highlighted that "part of the problem with any [community management] group that wants to manage [the natural resource separately from] making money from [the resource], is the idea that it's going to be an expense as opposed to an income". However, Participant C notes:

"It's not that there is not alignment in values and principles, it's just some of the technical bits and some of the understanding might be a wee bit different. The 
Māori values around water and its interconnectedness with everything is probably not a European concept. Which is not saying that either of them is wrong, but the issue is more understanding that...and working with that and actually get the outcome [decision making within the Ruamāhanga Whaitua Committee]".

Participant $C$ went further in explaining why there might be a divide between Indigenous and Western discourses on the Committee; “...that's the thing that through this process that Māori values are interwoven through, that a quite large number of us have had to improve our knowledge in that area". And "so I don't really think that the Māori values in the wider sense are limiting the wider conversation, by not covering stuff, I think pretty much everything slots into what we've [non-Māori] got. It's just the terminology." Participant $\mathrm{C}$ here is noting that while not all Māori views are understood, they believe there are equivalent non-Māori values that are more palatable for nonMāori committee members to use, but that they need them translated into a Western or more measurable context.

Significantly, Participant B notes the politics of translating complex ideas is not absent from the Whaitua Implementation Programme. The reduction of complex worldviews about interconnectedness to less complex viewpoints that may be more readily understood by the non-Mãori public is evident within the use of the phrase "Ki uta ki tai" in the Whaitua Implementation Programme processes (GWRC, 2018a). Participant B explains that "Ki uta ki tai is often seen as 'from the mountains to the sea'. But the Māori word for 'from' isn't 'ki, so ki uta ki tai means 'to the mountains to the sea'”. Ki uta ki tai is more about the cycle of water rather than the flow of it from the mountains to the sea, showing that converting Māori concepts into English and Eurocentric frames of reference can be problematic.

Participant D explained that the committee should "use numeric as a well as narrative" approaches to measuring and understanding waterways, but because of the dominance of the Western approach among members of the Ruamāhanga Whaitua Committee, 
decision making was pushed to work within a numerical framework. Participant $D$ notes that part of the values that were discussed within the committee are "not necessarily based in [Western] science", but that scientific or numerically driven values have "a big push by certain groups" behind them. Within the Greater Wellington Regional Council there are a number of different groups that work to manage the environment. Participant $D$ questioned if the committee and these wider resource management groups "are going to have the courage to say 'ok we need to start looking at river management a bit more holistically', rather than just zoning in on flood management". But this would "require some political will, to have the courage to make some big decisions". Participant D also stated that they thought that "it is a really big ask" to expect committee members to get their "heads around the ecology, hydrology, economics, farming systems, and cultural values" associated to the Ruamāhanga whaitua. Participant D highlighted that the committee "kept coming back to Part 2 of the RMA", and "all this stuff which others don't have a good grasp on, but need to". Here Participant $D$ is highlighting the level to which the Ruamāhanga Whaitua Committee is embedded in the Western legislative process, a process that not all Committee members are familiar with.

Participant E highlighted that the conflict between measurable and non-measurable values extended to questioning Māori practices. As part of the Ruamāhanga Whaitua Committee processes, some meetings were scheduled to take place on a marae (Māori meeting place). On a marae the format of speaking is different from a Western format and participation is not limited but rather takes on a more inclusive and participatory model. Participant E noted "there were some issues regarding a hui that was organised [for the Ruamāhanga Whaitua Committee]". And that committee members "questioned about why they needed to go to [the hui]...and that some people might not understand that we [the committee] have an obligation to talk to iwi". It was not completely clear from the participant interviews why some committee members did not want to go the hui. However, the hui occurred relatively late in the Whaitua Implementation Programme process and all committee members had already been to at least one hui. Such questioning of attendance at a hui may indicate that there is an understanding 
about Māori concepts, yet there is a lack of willingness for genuine engagement beyond the learning of concepts.

\subsection{Summary}

Members of the Ruamāhanga Whaitua Committee did in part agree on some values as they pertain to the environmental management of the Ruamāhanga whaitua. However, differences arose between the iwi representatives in the research and other committee members when it came to prioritising values for integration in the Whaitua Implementation Programme. The relative weight attached to these values, and the level to which committee members backed such values in discussion seems to be a product of a number of factors. Such factors included the number of Māori and non-Māori members on the committee, as well as the balance of the committee members' occupations (for instance there was a large number of members engaged in agriculture). Interestingly all participants made mention of the amount of time the Whaitua Implementation Programme process had taken in order to reach the final stages. Significantly, analysis of the interviews suggested that overarching national-level agendas set by the government have a trickle-down effect, and add weight to committee member's arguments for backing certain values over others. A compounding factor is how values are looked at, be they measureable or non-measurable, and if they need to be 'translated' from one cultural setting to another. There is a clear power differential between Māori and non-Māori, exemplified by the reluctance of non-Māori committee members to attend a hui, while Māori committee members are expected to participate in European-orientated meeting format each time the committee gets together. 


\section{Chapter Five}

\section{Discussion}

This chapter will discuss the findings of the research with reference to the previous literature around Indigenous knowledge, Māori environmental management, environmental management politics, and how power manifests itself in environment management. Specifically, this chapter considers the three main themes to emerge from the research: (i) the values of the Ruamāhanga Whaitua Committee and how power differences among members of the Committee influences the incorporation of Māori values in environmental management decision making; (ii) the wider postcolonial context for the relative prioritisation of Māori and non-Māori values by the Ruamāhanga Whaitua Committee; and (iii) the conflict of Indigenous and Western viewpoints alongside the language of values. The difference between Māori partnership and Māori as stakeholders in the environmental management setting will be highlighted throughout the discussion, with specific attention focused on where the Whaitua Implementation Programme sits with reference to partnership and stakeholder forms of co-management.

\subsection{Values of the Ruamāhanga Whaitua Committee}

This research found that both Māori and non-Māori members of the Ruamāhanga Whaitua Committee share some of the same environmental values. These values include more holistically centred approaches to environmental conservation, such as kaitiakitanga. While not all members of the Committee initially understood Māori values, members made an effort to understand and gain an appreciation of Māori values. It is clear from previous studies that individuals from separate cultures can share and agree on environmental values (Ens et al., 2015; Fernandez-Gimenez et al., 2007; Stefanelli et al., 2017). So it is not unusual for the Māori and non-Māori members of the 
Ruamāhanga Whaitua Committee to agree on the same values. However, there was a clear difference between values Committee members could agree upon, and the willingness of non-Māori members to adopt these values as the basis of their action and decision making.

\subsubsection{Discrepancy between values and behaviour}

All members of the Ruamāhanga Whaitua Committee hold broadly similar views around what the environment means to them and how it should be treated. However, in the case of some members, some views tend to be held independently of how they believe the environment should be used. That is, there is a discrepancy between some of the attitudes of non-Māori Ruamāhanga Whaitua Committee members towards Māori values and their behavioural decision making. This discrepancy between attitudes (or values) and behaviour has been termed the 'value-action-gap' (Blake, 1999; Kollmuss \& Agyeman, 2002).

Study of the value-action gap is part of a wider body of literature that looks at environmental management behaviours. These behaviours include the expression and conflict of different values in an environmental management situation. Environmental management behaviours are influenced by both internal and external factors (Kollmuss \& Agyeman, 2002). External barriers to positive environmental behaviour include politics, economics, society and cultural factors (Kollmuss \& Agyeman, 2002). These factors are especially relevant to the functioning of the Ruamāhanga Whaitua Committee. As noted previously, the Committee is managed and structured by the Greater Wellington Regional Council, and is made up of a variety of people from different economic situations and cultural backgrounds from throughout the Ruamāhanga whaitua community. Due to the proximity to political structures, and the innate nature of cultural and economic diversity within the Committee, members are susceptible to environmental behaviour barriers, in particular the discrepancy between values and behaviour. The members of the Ruamāhanga Whaitua Committee are individuals that are part of the community and the environment in which they are tasked 
with managing. As such they have a vested interest in the outcome of the management process. However, while this vested interest is good in that it means members are more likely to know and care more about outcomes of the process, alternatively it can make them more susceptible to factors that prevent some of their values from turning into actions (Lacroix \& Gifford). The findings of the research found that political, economic, social and cultural factors could cause a disconnect between commonly agreed Māori values and related environmental management actions. This discrepancy between values and behaviour resulted in Māori values being side-lined as part of the Whaitua Implementation Programme.

\subsubsection{Politics as a contributor to the value-behaviour discrepancy}

Lacroix and Gifford (2017, p. 5) identified a 'lack of political action' as one of the factors that can cause a discrepancy between values and environmental management behaviour. The Ruamāhanga Whaitua Committee is positioned within an established political structure, which reduces its ability to produce beneficial environmental outcomes for the community. The Ruamāhanga Whaitua Committee sits beneath a higher governing committee called Te Upoko Taiao. As such the power of environmental decision making for the Whaitua Implementation Programme effectively lies with Te Upoko Taiao, and the Ruamāhanga Whaitua Committee simply provides recommendations. Te Upoko Taiao consists of equal Māori and non-Māori members, fulfilling the Greater Wellington Regional Council's mandate to act in partnership with Māori. However, on the Ruamāhanga Whaitua Committee iwi are designated within the Whaitua Committee Terms of Reference, set up by the Greater Wellington Regional Council, as stakeholders rather than partners.

As a result of iwi representatives being positioned as stakeholders on the committee, the balance of power shifts towards non-Māori members. Thus there is a lack of political pressure to account for Māori values at the Ruamāhanga Whaitua Committee level. The political structures and political power within the Whaitua Implementation Programme process, and particularly the non-partnership structure at its lower levels, enables non- 
Māori actors on the Ruamāhanga Whaitua Committee to behave and act in a way that is contrary to their 'shared' values they have with Māori. Participant B, in the research noted how even being labelled as a stakeholder reduces the legitimacy, and in effect the power iwi have at the decision-making table. The view that Māori are more than just stakeholders in environmental management, and they are rather partners, may go some way to disrupting the current power structures within management committees. As Howitt and Suchet-Pearson (2006b) identify, such disruption of power structures are key to starting and sustaining the decolonisation process. The idea of decolonisation in environmental management will be expanded on further later in this chapter.

Political pressure is an external factor identified by Kollmuss and Agyeman (2002) that can sometimes positively impact the value-behaviour discrepancy. Beneficial political pressure, in the case of the Whaitua Implementation Programme, can been seen as the pressure through which Māori values are brought to the forefront of environmental decision making. Such positive political pressure has been enabled through apparatus like the memorandum of partnership between the Wellington Region's iwi and the Regional Council, as well as local level government legislation. Political pressure in the case of the Whaitua Implementation Programme can be beneficial for the expression of Māori values. However, the majority of beneficial political pressure is acted upon at the higher Te Upoko Taiao level. Thus, political pressure that benefits the expression of Māori values is not being applied universally across the whole of programme. Political pressure at the Ruamāhanga Whaitua Committee level is significantly reduced due to the higher level political structures in place. The Greater Wellington Regional Council's inability to provide political pressure throughout the different committee levels enables a discrepancy in the values and behaviour expressed by non-Māori members of the Ruamāhanga Whaitua Committee. The findings of this study suggest that such factors, like the number of Māori committee members on the Ruamāhanga Whaitua Committee, could alter the discussions that take place around environmental values. Increasing the number of iwi representatives, or balancing the number of non-Māori and Māori voices could put the greatest decision-making power at the community level. Such shifts in political pressure would go some way to fulfil the Greater Wellington Regional Council's 
obligation to work in partnership with Māori for environmental management to a greater degree.

The political processes involved in producing the Whaitua Implementation Programme can also impact the expression and adoption of Māori values on the Committee. The political processes involved takes a long time to produce an outcome and the Whaitua Implementation Programme for the Ruamāhanga whaitua took a significant amount of time and energy to produce. The Ruamāhanga Whaitua Committee was formed in December 2013, and submitted its Whaitua Implementation Programme in late 2017. All of the participants in the research commented on the length of time that the political processes have taken, and the time it has taken the Ruamāhanga Whaitua Committee to come to an agreement on the recommendations to put forward for the Whaitua Implementation Programme. The extent of time the political process takes can also have implications for how Māori values are discussed by the committee. Again it is important to highlight that there are only two iwi representatives (i.e., representatives of Māori values) on the Ruamāhanga Whaitua Committee. While the research found that values consistent with Māori environmental values are not solely held by iwi representatives, they alone are the voice and representatives of the tangata whenua. As such, iwi representatives tend to become the first voice in defence against opposition to Māorisupported values. Any opposition to the incorporation of Māori values as part of the Committee's decision making process has a sustained time frame in which to operate, and a numerical member advantage. Thus, there is a greater opportunity to reinforce the discrepancy between values and behaviours of some of the Committee members. The reinforcement of the value-behaviour discrepancy is a result, in part, of the long political process of environmental decision making.

\subsubsection{Capitalism as a contributor to the value-behaviour discrepancy}

Capitalism has particular relevance and impact on the discrepancy between values and behaviour of the members of the Ruamāhanga Whaitua Committee. Here it is important to differentiate the economy and capitalism. Gibson-Graham (1996) argue that more 
often than not the idea of capitalism and economy are conflated. The economy is everything that sustains human lives, much of which is not part of capitalism. In comparison, capitalism is not about sustaining, rather it is about producing capital or profit. As Gibson-Graham (1996) note, capitalism operates within a growth-orientated economic system. Gibson-Graham (1996) conclude that the 'economy' is not capitalism's exclusive domain, an important notion when discussing how economic factors can effect a value-behaviour discrepancy within members of the Ruamāhanga Whaitua Committee. Farmers make up the biggest group within the committee, and are economically highly reliant on the certainty of environmental management. Economic factors are intertwined with social, infrastructural and psychological factors (Gifford, 2011). Rather than economic factors producing a value-behaviour discrepancy, it is really the product of the current economic system.

Economic factors, including capitalistic tendencies, have a strong influence on people's decisions and behaviour (Kollmuss \& Agyeman, 2002). Schewe and Stuart (2017) in the context of climate change, highlight that external economic structures can influence farmers' environmental management decision-making behaviour. Significantly Schewe and Stuart (2017) argue that competitive business, or scenarios in which money or financial gain or security is a stake, can actively discourage pro-environmental behaviour. Thus, members of the Ruamāhanga Whaitua Committee who are farmers are subject to capitalist pressures because of the nature of production-based farming in Aotearoa New Zealand. Three participants in the research expressed views that the capitalist values of some farmers on the committee influenced their behavioural decision making. Additionally, Dahl (2015) notes that the lack of opportunities for communication between people engaging in environmental management might facilitate the tendency for some actors to maintain their capitalist thinking and prioritise production over nature conservation. The lack of opportunities for communication can stem from cultural differences in expression. 
Additionally, the current Aotearoa New Zealand economy is orientated towards particular forms of growth that are often at the expense of environmental health, and the pressure of being a business owner in the current economy shapes the way some members of the committee made decisions. For example, it is in the interest of the farmers on the Ruamāhanga Whaitua Committee to have the limit on how much water can be taken from the freshwater resources as high as possible. Promoting a high-water use limit approach to water management tends be at the expense of environmental values orientated around culture and society. As discussed above, values that promote the environmental and societal wellbeing are important to many members of the Ruamāhanga Whaitua Committee members, but significantly these values tend to be higher priority for Māori, including the iwi participants in the research interviews. Thus, I would argue that having people with a capitalistic or business mind-set, as a majority on the committee alters the discussion around values, in favour of economically orientated values, at the expense of environmentally orientated Māori values.

\subsection{The prioritisation of values}

This research has revealed that there is a gap between values discussed by the Ruamāhanga Whaitua Committee and decision making of the Committee. Due to the political structures and the individuals who make up the committee, values around capitalism end up taking prevalence over cultural and social environmental values. In this section of the chapter I discuss the wider contextual processes that have produced the uneven prioritisation of certain values over the cultural and social values that were expressed by iwi representatives on the Ruamāhanga Whaitua Committee. Subsequently, how such contexts can potentially influence the uptake of iwi values and environmental management decision making of the Ruamāhanga Whaitua Committee will be discussed. 


\subsubsection{Colonial histories and postcolonialism}

To understand the structures in which the Ruamāhanga Whaitua Committee exists, and thereby the pressures and influences the committee and its members are subject to in their environmental decision making, it is important to consider the effect colonialism and postcolonialism has had on Aotearoa New Zealand. Colonialism and postcolonialism, which are present in throughout Aotearoa New Zealand society, have produced a power differential between Māori and non-Māori members on the Ruamāhanga Whaitua Committee. All committee members are subject to this power imbalance. Colonialism can be understood as the processes and tangible effects of the appropriation on the land and people by an outside power, alongside the establishment of a racialised hierarchy as a result of that appropriation (Porter, 2006; Smith, 2005). Colonialism goes to the core of Aotearoa New Zealand's society in that the structures of economy and power between the colonisers and colonised reach local communities and community management groups (Coombes, 2007; Porter, 2006). To be postcolonial is to be both within and beyond those established colonial structures and relationships, and acknowledge and understand the sustained presence of colonial process and the effects they have (Coombes, 2007; Parsons \& Harding, 2011; Porter, 2006). Porter (2006) describes Aotearoa New Zealand as a postcolonial nation, and as such Aotearoa New Zealand continues to be shaped by the racialised assumptions and marginalisation of Māori from mainstream culture, even though the most visible processes of colonialism appear to have subsided.

Marginalisation stems from the actions of people within a postcolonial system. Yet actors are the end result or proximate cause of any marginalisation. Attention needs to be drawn to the ultimate cause of marginalisation - that is, the system in its self. The Ruamāhanga Whaitua Committee, and the people who are actors within it are products of a system that is rooted in colonial power tendencies and relations. It is the belief that Indigenous knowledge 'needs' Western science that entrenches the idea that those conducting or partaking in Indigenous knowledge cannot operate simultaneously in the role of decision making (Brosius, 2004; Coombes, 2007). The attempt to incorporate Māori values in the Ruamāhanga Whaitua Implementation Plan sit outside the historical 
Western/Eurocentric knowledge. It is this history of Western knowledge in environmental management that produced the marginalisation of Māori values in the Ruamāhanga Whaitua Committee. The incorporation of Māori values challenges the established power structures in environmental management systems in Aotearoa New Zealand. It is a difficult but necessary process to start to decolonise environmental management systems, and take or alter power away from those actors who have held it for so long. The reluctance of people in power, like Western scientists, to relinquish the decision-making power to which they have become accustomed, contributes to the resistance and reticence to incorporate Māori values in the decision making of the Ruamāhanga Whaitua Committee. Without a shift in the political power structure present in modern day Aotearoa New Zealand, community-based environmental management such as the Whaitua Implementation Programme, will struggle to successfully include Māori values.

In recent decades there has been a greater incorporation of Indigenous knowledge in Aotearoa New Zealand's political systems through such regional organs as the Ruamāhanga Whaitua Committee. Such incorporation has been partly driven by legislation - including the RMA (1991) and Local Government Act (2002) - and Māori leadership. Yet there is retention of a "command-and-control" approach (Coombes, 2007, p. 187) to environmental management that has the same consequences for Māori values as conventional imperialism. Such a 'command and control' approach persists, and the incorporation of Indigenous knowledge often fails to transcend cultural and ideological boundaries. Resultantly, colonial and Western discourse and power relations still perpetuate in environmental management. Such Western discourse and power structures are clearly present in the Ruamāhanga Whaitua Committee as iwi values are marginalised.

\subsubsection{Power outside of community-level environmental management}

Power relations and structures outside of community-level management can impact the incorporation of Māori values in environmental management. For example, Coombes 
(2007) highlights the power and control that state managers have over environmental management processes in Aotearoa New Zealand. Limits on how much Indigenous knowledge is incorporated enables the preservation of the power held by the state and its actors over Māori and Māori-oriented values. Porter (2006) explains that even the inclusion of Indigenous 'voices' as a stakeholder is an act of power in itself because such an insertion is defined and legitimised by the state. The stakeholder position is a product of the postcolonial system which marginalises Indigenous voices. The rights for Indigenous knowledge to have an impact on decision making continue to be in the hands of the state, founded on the appropriation of land (Porter, 2006). This idea is exemplified in the Whaitua Implementation Programme processes because the Ruamāhanga Whaitua Committee is run by the Greater Wellington Regional Council, who can significantly influence the inclusion of Māori values in the management process.

The wielding of state power in Aotearoa New Zealand in opposition to Māori values and knowledge is obviously not limited to regional councils such as the Greater Wellington Regional Council. For example, the Department of Conservation (DoC) in the past has prohibited the harvest of cultural materials which they deem to be 'inappropriate' in order to prevent the economic application of environmental resources (Coombes, 2007). The prohibition on the harvest of materials by DoC ironically enables the state to define the terms of 'cultural use' that are subsequently imposed on Māori. Coombes (2007) highlights that there was no distinction between cultural and commercial use in pre-colonial times and the imposition of such an idea by DoC is clearly ethnocentric. Here we can see that the remnants of colonial ideas still persist in controlling and deciding where and how Indigenous knowledge may be used in Aotearoa New Zealand. Colonialism has created a setting in which the majority of management must be undertaken in Aotearoa New Zealand by a state body, taking power away from Māori and into the hands of non-Māori actors that are often less than willing to give up power. Clearly, Māori do have a voice as part of the Whaitua Implementation Programme, but this is more of an indication of the postcolonial political setting in which environmental management processes in Aotearoa New Zealand function, rather than a genuine equal 
transfer of power to Māori to determine the management of the local environment in which they live.

Alongside the impact of government control on the Ruamāhanga Whaitua Committee through centralised policies, the underlying political philosophy of the (previous) government's agenda also exerted power on the committee. The fifth National government of New Zealand (2008-2017) had an agenda where economic polices focused on a market-led and business-focussed approach, at the expense of social and community consideration ( $\mathrm{Nel}, 2014$ ). Participants A, B, D and E felt that the proeconomic status of the National government galvanised and empowered a prioritisation of capitalistic ideas within the committee. That is, members of the committee felt more comfortable confronting non-capitalistic, environmentally and socially orientated values and promoting economic values because they felt justified by the government's economy first-agenda.

\subsubsection{Decolonisation in environmental management}

There is a need to understand, acknowledge and account for colonial roots and postcolonial processes in environmental management. Actors in environmental management need to accept that the practices, values and knowledge that are involved in the daily practices of environmental management in Aotearoa New Zealand are in themselves complicit with the on-going colonial domination of place, and people (Howitt \& Suchet-Pearson, 2006b; Thomas, 2015). Actors on all levels need to examine management processes (such as how members of a community management committees are selected) that were previously thought of as neutral, and to bring an examination of such processes to the very core of discussion with Indigenous groups about methods for environmental management. For example, members of the Ruamāhanga Whaitua Committee were selected by the Greater Wellington Regional Council. Committee members were selected based on a number of criteria including, balancing committee membership with regards to interests in agriculture, indigenous biodiversity and the environment, tangata whenua values, recreational use, wider 
economic development, and urban concerns (GWRC, 2018a). An approach that may have created a more balanced committee might have involved the two iwi with mana (prestige/authority) over that takiwā (area) in appointing committee members. The Whaitua Implementation Programme is a local attempt to highlight and address the uneven balance of power within environmental management in Aotearoa New Zealand, which in part results from postcolonialism. Yet, as a result of the persistent and deeply rooted postcolonial process of environmental management, there still seems to be an unbalanced nature to the way Māori values are viewed and accounted for in the Ruamāhanga Whaitua Committee's decision making.

Indigenous values can challenge Western societies, and ways of management, in aid of the effort to destabilise power structures. The task for communities and actors to destabilise such power structures in environmental management is to challenge the power inequalities at play. Such power structure include those which have led to the imbalance in the prioritisation of Māori values by the Ruamāhanga Whaitua Committee. Howitt and Suchet-Pearson (2006b) note that there can be the simultaneous existence of multiple understandings of the world, but the task is to address the dominance of particular worldviews over others. In order to addresses such dominance in environmental management, the processes of decolonisation needs to take place. Such decolonising of decision making concerning the environment must begin with the acknowledgement of the unique rights of Indigenous people and increased Indigenous control over such a process

A disparity in iwi representation on the committee potentially puts Māori values (as represented by iwi) at a serious disadvantage to the established Western views. For Māori values to be given a chance to challenge Western views there needs to be political practices that enable the established power balances to be rejected so that management decisions can be contested. As Thomas (2015) argues, such contention usually takes the form of contending the dominance of the Western nature of society in formal environmental decision-making process. The study by Thomas (2015) provides a 
clear example of where the processes of colonialism and postcolonialism are being challenged. The iwi Ngāi Tahu, who despite facing uncomfortable negotiation processes, were successfully able to slowly allow for rivers to be seen as actors in themselves. Ngāi Tahu showed how political power structures surrounding environmental management could be challenged and decolonised. This action by Ngāi Tahu provides an example where political processes and structures need, and have to ability to change.

There are processes in place to start reducing or altering the power structures that are a product of colonisation in Aotearoa New Zealand. The Waitangi Tribunal (1975) was formed to settle Māori grievances as a result of Crown actions, including illegal land grabs and 'sales' under the 1840 Treaty of Waitangi (Ginn, 2008; Smith, 2005). However, such a need for Māori claims to be validated through The Waitangi Tribunal (a European modelled legalistic setting) is in itself a form of postcolonialism (Smith, 2005). To resolve the histories of colonialism and move away from the postcolonial era in which Aotearoa New Zealand finds itself requires not only a willingness to engage with active decolonising methods, but a recognition of power relations that have been, and are, operating in an environmental management situations (Porter, 2006). In the case of the Ruamāhanga Whaitua Committee, it was revealed by the research that there were very few marae visits and non-Māori members vocally objected to having meetings on the marae. Such examples from the Committee do not show Porter's (2006, p. 388) "willingness" to get involved, and so it would appear that the processes of decolonisation (be it deliberate or not) are struggling to operate within the Ruamāhanga Whaitua Committee, in part as a result of outside political forces.

If state-run management practices such as the Whaitua Implementation Programme are to benefit from Indigenous knowledge, Porter (2006) notes that government agencies need to willingly address colonial legacies and accept Indigenous self-determination. To further Indigenous self-determination, government agencies must not only accept, but actively promote Māori values and ideologies as their own separate and individual processes. However, even in the best-case scenario when power relations are well 
understood, actors must be aware that current environmental management in Aotearoa New Zealand has its own genealogy that is rooted in colonialism. In forgetting to theorise and account for environmental management's own cultural position, management bodies like the Greater Wellington Regional Council, render Māori values in environmental management decisions a simple contributor rather than a driving partner, which is just a continuation of the expression of colonial power.

\subsubsection{Power within community environmental management}

Community-based environmental management programmes are typically founded on the premise that compared to state managers, local populations have a greater interest in local environmental resources, and thus should be better equipped to understand the issues and contribute to effective management (Brosius et al., 1998). However, Brosius et al. (1998) note that there is internal differentiation and dynamism within local communities which can influence the effectiveness of the management. Leach et al. (1999) notes that to date, the inability to properly understand such dynamic power structures has impeded the ability of community-based management to produce representative outcomes for the community.

The correction of internal power structures and politicisation of community management, as represented by the Whaitua Implementation Programme, will require an approach which considers seriously how power relations between actors involved in the community process work (Leach et al., 1999). It must not be assumed that community management rises above historic and ingrained political conflicts. For example, a study by Walker and Hurley (2004) found that the demise of a community management group in Nevada, USA was the result of a power struggle between two subgroups within the group. The management group functioned as a mechanism through which power was circulated within the community (Walker \& Hurley, 2004). In the same vein, Palmer (2006) conducted a study around the Indigenous Bininj/Mungguy people's attempt to seek management of the Akakadu National Park in Australia. The political influence of vocal stakeholders and lobby groups within management groups 
continuously acted as barriers to the attempts of the Bininj/Mungguy to manage the land use according to their values. Through such political influence, the apolitical 'nature-centre' vision of how the Bininj/Mangguy wished to manage the environment was overridden.

It is clear from the research that power imbalances can be felt both internally within the Ruamāhanga Whaitua Committee and from external state political structures. As a result, the incorporation of iwi values (as representative of Māori values) as part of the Whaitua Implementation Programme face serious opposition and challenges. The structures and powers that are innate to the Greater Wellington Regional Council, and resultantly the Whaitua Implementation Programme and Ruamāhanga Whaitua Committee remain complicit in the continuation of postcolonial structures in Aotearoa New Zealand.

\subsection{The language of values and Indigenous and Western viewpoints}

The final theme to emerge from the interviews with participants in the research is the linguistic context in which Ruamāhanga Whaitua Committee discussion takes place. This section will discuss how Indigenous and Western knowledges interact as well as how lessons from the expression (and suppression) of Māori values in education can be applied to environmental management.

\subsubsection{Indigenous and Western knowledges}

Fernandez-Gimenez et al. (2007) note that from their study of a co-management organisation in Alaska (USA), that the application of traditional knowledge in contemporary science based-management settings is slow. The combination of Indigenous knowledge and Western science in the co-management organisation has influence on management decisions. But in many instances traditional knowledge has conflicted with scientific findings, and some traditional knowledge was perceived to be 
irrelevant to the science. Importantly, Fernandez-Gimenez et al. (2007) reported that there was the awareness, particularly by Indigenous actors, of the underlying power dynamics of Indigenous involvement in research and management. Both iwi representatives as well as other participants in the research expressed ideas that indicated an understanding around the inequalities of the systems of environmental management. Science, Fernandez-Gimenez et al. (2007) note, was used as a form of 'validation' of traditional knowledge, i.e., scientific credibility was a benchmark to which traditional knowledge was compared, and thus held power over the credibility of traditional knowledge.

Despite the conflict between Indigenous and Western knowledges, Fernandez-Gimenez et al. (2007) note that a number of factors can result in the satisfactory management of an environmental resource from both the Western and Indigenous viewpoints. Such factors include: equal voting rights of Indigenous and non-Indigenous members; the large number of Indigenous members in comparison with non-Indigenous members; and multiple Indigenous venues where meetings take place. Such factors ensure that power is actually shared, the research is set in a transparent manner, and there is genuine effective communication between group members (Fernandez-Gimenez et al., 2007). Of the three crucial factors that Fernandez-Gimenez et al. (2006) highlight for successfully combining Indigenous knowledge and Western science, the Ruamāhanga Whaitua Committee only has equal voting rights. In order for the committee to decide upon the recommendations proposed within the Whaitua Implementation Programme, the committee must reach a consensus (GWRC, 2018a). Significantly, all participants in the research commented on the importance of having to reach a consensus. Participants explained that having to reach a consensus forced the committee to discuss and work with one another, and was viewed by the iwi participants as an overwhelmingly positive factor, despite its sometimes conflicting manner. Having to reach a consensus as a Ruamāhanga Whaitua Committee can contribute to the breaking down of some power structures within the committee, because every single person wields equal power to promote or demote an issue or value (i.e., equal voting rights). Despite the committee having to reach a consensus there were still significantly more non-iwi representative 
members on the committee, which is likely to affect the consensus reached by the committee.

Finally, the Ruamāhanga Whaitua Committee failed to regularly visit marae for meetings. While not a requirement under the committee's Terms of Reference, it is an important point to discuss in terms of the conflict of Indigenous and Western knowledges. As noted earlier in this discussion, one participant in the research explained that a potential committee meeting on a marae was actively questioned by non-Māori members of the committee. Such questioning eventuated in the meeting being moved from the marae to a 'regular' meeting place. It can only be assumed that such a 'regular' meeting place fitted into the more comfortable image of Western viewpoints held by the non-Māori members of the committee. By resisting moving outside of their comfort zone, non-Māori members are prioritising themselves and their values over those of iwi representatives on the committee. Similarly, by holding the majority of meetings away from the marae of iwi representatives, the power that relates to place (and its implications) is firmly favouring non-Māori representatives.

\subsubsection{Aotearoa New Zealand and Māori values}

A significant factor in the conflict between Indigenous and Western knowledges in Aotearoa New Zealand is the poor understanding of Indigenous history and culture by the non-Māori population in society. This poor understanding stems from Western educational structures (Bishop, 2011; Ens et al., 2015). There is a real failure within central governmental policies to account for Māori history and cultural teaching in the state schools of Aotearoa New Zealand. As such there is poor recognition of the Māori language and Māori cultural practices by Aotearoa New Zealand's wider society (Glynn, 2015).

The poor understanding of Māori values need to be addresses if Māori values are to be able to have a chance to gain equal standing in society. The challenge of advancing 
societal understanding of Māori values is exemplified in Aotearoa New Zealand's educational systems. Glynn (2015) notes that within education sectors that are controlled by Māori and for Māori, Māori culture and knowledge has been able to flourish. But in the mainstream, where the majority of Māori are educated alongside the rest of citizens from Aotearoa New Zealand, there is still large amounts of work to be done by education professionals, and one would argue, the governmental policies which guide such professionals. For Māori values to effectively challenge the Western norms, Māori cultural education must take place within the mainstream education sector. For such a change to take place, environmental management actors must understand the importance of Māori culture and the knock-on effects it can have, and governmental education policies must reflect the growing decolonisation processes happening within wider society. As this research has shown the inclusion of Māori knowledge and values has been restricted through the systematic processes that are involved in the Ruamāhanga Whaitua Committee. There is an argument that the Ruamāhanga Whaitua Implementation Programme, while having the right intentions has not done enough to account for and incorporate Māori values. If there was absolute belief in Māori values and the willingness to give up power by the established structures, there would be more iwi representatives on the Ruamāhanga Whaitua Committee, as well as a drive to use Māori values as the foundation of water management in the whaitua. 


\section{Chapter Six}

\section{Conclusion}

This research set out to understand what influences the incorporation of iwi values (as representative of Māori values) in the Greater Wellington Regional Council's Ruamāhanga Whaitua Committee's Whaitua Implementation Programme. Semistructured interviews were used to collect information on the thoughts of members of the Ruamāhanga Whaitua Committee. The findings of this research show that community-level environmental management in Aotearoa New Zealand is subject to postcolonial processes and structures. Aotearoa New Zealand's political, cultural and social structures create power inequalities that can, in the case of the Ruamāhanga Whaitua Committee, act as significant barriers to the incorporation of Māori values into environmental management decisions.

The final chapter of the thesis will summarise the main arguments and conclusions of the research, address the limitations of the study, outline some avenues for potential future research, and offer some recommendations around how regional councils could address the barriers facing the inclusion of Māori values in environmental management.

\subsection{Summary of findings}

The Ruamāhanga Whaitua Committee is a product of the Greater Wellington Regional Council's Proposed Natural Resource Plan. As such it is situated within a state process that produced a number of effects that were felt by the iwi representatives of the Whaitua Committee. It is clear from the research that there is a discrepancy between the values and behaviours expressed by some non-Māori members of the committee, which importantly influenced the recommendations made by the committee. Such a discrepancy was a result of the political structure of the Greater Wellington's Regional Council's Whaitua Implementation Programme process. Political structures also resulted in decision-making power being situated 'higher' up in the organisation with Te Upoko Taiao. Alongside the political structures, the economic ideology of capitalism, and 
its ties to the agenda of the government of the day, resulted in more power being given to those committee members who were more likely to support capitalistic ideologies. The result of greater power residing with this group of committee members made it far easier for the behaviour of these members to deviate from Māori-related values which they may hold (but do not align with capitalistic ideologies). As a result of this valuebehaviour discrepancy, discussion around Māori-orientated cultural and societal values was side-lined, and decision-making power was reduced for iwi representatives on the committee.

It is evident that the colonial history of Aotearoa New Zealand, and current postcolonial structures in which environmental management sits, has resulted in an uneven power balance on the Ruamāhanga Whaitua Committee, in favour of non-Māori representative members. This was demonstrated when some Committee members questioned and objected to the need to hold committee meetings on marae. The research also revealed that iwi representatives were positioned as stakeholders, not partners in the decision making of the Committee, which breaches the guiding principles created as part of the regional plan review process. Such a power imbalance favours the established Western viewpoint and values of the natural environment, marginalising some iwi (and therefore Māori) viewpoints and values in environmental management. Further to this, Māori and Western knowledges conflicted with one another in the Ruamāhanga Whaitua Committee, in part because of a reluctance by non-Māori committee members to accept Māori cultural practices as part of the discussion around values (e.g. hui at marae). More broadly, poor understanding and acceptance of Māori culture within non-Māori society, exacerbated by the education system in Aotearoa New Zealand, is slowing the process of decolonisation in the environmental management setting. The structures and powers that are innate to the Greater Wellington Regional Council, and resultantly the Ruamāhanga Whaitua Committee, remain complicit in the continuation of postcolonial structures in Aotearoa New Zealand. Thus, without broader societal and structural change, the barriers that iwi face in environmental management will persist within the Whaitua Implementation Programme. 
The findings of this research indicate that the Whaitua Implementation Programme, in the case of the Ruamāhanga Whaitua Committee, is not effective at incorporating iwi values in the management of the Ruamāhanga whaitua. While the Greater Wellington Regional Council should be commended for setting up Te Upoko Taiao, where iwi are in partnership with the council, such a concept of partnership does not extend to the Ruamāhanga Whaitua Committee. Whether the lack of partnership at the committee level is a product of the council feeling it has fulfilled its obligation to act in partnership at the higher-level Te Upoko Taiao, or a lack of trust or neglect, the result is the same. Without the ability to act in partnership in the Ruamāhanga Whaitua Committee and, alongside other more deeply rooted barriers, it is possible for some non-Māori Committee members to project their values over those of the two iwi representatives. The result of such power inequality is that iwi values are not adequately prioritised in the Ruamāhanga Whaitua Committee decision-making process.

This research has contributed to an understanding of how Māori (through iwi) are included in current freshwater management schemes within the system of the government of Aotearoa New Zealand. Significantly, this research has identified that while still situated in an environment that mandates the inclusion and incorporation of iwi values, postcolonial systems, power structures and a lack of willingness to commit to decolonisating processes can result in significant barriers to the inclusion of Māori values in environmental management. As such, this research has also contributed to the body of literature around the processes of decolonisation in Aotearoa New Zealand, addressing how decolonisation may (or may not) manifest itself within the many actors of environmental management, as well as the barriers that decolonisation may encounter. However, there were a number of limitations to the study.

\subsection{Study limitations}

The limitations of this research relate directly to the narrow scope of the research. The choice of a single case study is justified due to the scale of a 90 point Master's project, and because of the limited progression of the only other Whaitua Committee to have 
been so far established in the Wellington region. However, it would have been beneficial to have comparative case studies in order to determine if the results from the Ruamāhanga Whaitua Committee study were generalisable to a wider setting. It would have also been interesting to analyse and discuss with iwi committee members their thoughts on the final Ruamāhanga Whaitua Implementation Programme once it had been submitted to the Greater Wellington Regional Council, and to examine what aspects of the Ruamāhanga Whaitua Implementation Programme made it into the Regional Natural Resource Plan. Unfortunately, it was not possible to fit such an analysis within the timeframe of the project, because the Ruamāhanga Whaitua Implementation programme was only made available late in December 2017.

It would have been ideal to interview all members of the Ruamāhanga Whaitua Committee in order to understand the whole of the Committee's perspectives on the incorporation of iwi values into the Whaitua Implementation Programme. Other Committee members were contacted, but did not respond to requests to be interviewed and be part of the research. Similarly, it would have been useful to have widened the scope of the research to interview members of Te Upoko Taiao and Greater Wellington Regional Council employees. The inclusion of these people as part of the research would have expanded my understanding of the partnership arrangements on Te Upoko Taiao, and I would have gained a perspective from the Council on how well it though iwi values were incorporated into environmental management. However, this was beyond the scope laid out for this research and therefore would form an interesting area for further study.

\subsection{Future research}

In addition to the widening of the scope of the research project as noted above, future potential research avenues were revealed by this Research.

The main prospect for future research that has come out of this research relates to the language of policy and state interpretation in freshwater management. There have been 
numerous analyses of how language has been used in Aotearoa New Zealand's history to marginalise Māori culture, beliefs and people (inc. Moon \& Fenton, 2002; Shamma, 2018). An interesting avenue to follow would be to investigate how the language of freshwater policy gives government authorities the ability to act or interpret the policy as they see fit, for example the difference in mandated partnership or stakeholder positions. Such an avenue would draw on the evidence from this study that the Greater Wellington Regional Council accounted for iwi partnership at a higher level (Te Upoko Taiao), which resulted in an impact of the representation of iwi values at the lower community level (Ruamāhanga Whaitua Committee). Such research could produce recommendations around how to best frame policy so that iwi values, and more broadly those of Māori, could be more adequately incorporated in freshwater management decisions.

Additionally, there is scope for research in Aotearoa New Zealand outside the freshwater management environment. Freshwater in Aotearoa New Zealand is of high social, cultural and physical importance, and as such has attracted the corresponding amount of academic attention. It would be interesting compare how iwi values are incorporated in other small government-lead community management schemes in the marine and terrestrial environments.

\subsection{Recommendations}

The Greater Wellington Regional Council has shown that they are committed, through Te Upoko Taiao, to entering a partnership with iwi in environmental management. However, because iwi are stakeholders at the Whaitua Committee level, the processes of decolonisation in environmental management has yet to be fully realised. The Greater Wellington Regional Council has three more Whaitua Committees to facilitate in the coming years. As a result of this study, I recommend that the Council work to be consistent in its commitment to partnership with iwi throughout all the levels of the Whaitua Implementation Programme process. Partnership in this context can simply be defined as iwi members having equal representation as other community members and 
local governmental representatives. Partnership consistency right down to the Whaitua Committee level has the real ability to create an environment for decolonisation processes to take place, and thus empower iwi representatives and values to the point where Māori values can have a lasting impact on environmental management. Adopting such a process would make the Greater Wellington Regional Council an exemplary organisation for the incorporation of iwi and Māori values as a part of freshwater management in Aotearoa New Zealand. 


\section{Appendices}

\section{Appendix 1: Phase I Interview Question Guide}

\section{Interview Question Guide - Phase I}

Interview aim: to discuss with Ruamāhanga Whaitua Committee iwi members (Rangitāne o Wairarapa and Ngāti kahungunu ki Wairarapa) what environmental values they hold and what values are associated with the Ruamāhanga whaitua.

\section{Background}

- Tell me about yourself.

- How long have you been on the Ruamāhanga Whaitua Committee (RWC)?

- How did you get involved with the RWC?

- What is your position on the RWC?

\section{Environmental Values}

- Please tell me about your iwi's relationship with the waterways in the region.

- Do you recall any stories about the waterways in the region?

- How is your iwi involved in the whaitua?

- Does your iwi take part in processes that promote the health and/or management of the whaitua?

o How?

- Are there any traditional resource management systems that are (or were) used in relation to the Ruamāhanga whaitua?

- What are the key values for your iwi in relation to waterways?

- What would you say is the greatest value a river can give to the iwi? (If you think there is no single standout value, please say so).

- Tell me about the process by which the whaitua values were identified by the RWC.

- Is there anything missing from these values?

- Is there a value(s) that could be emphasised more?

- Is there a value(s) that could be emphasised less?

\section{Changes/Recommendations}

- What do you think is the main problem (if perceived to be so) facing the inclusion and/or implementation of Māori values in the RWC? 
- Are there any changes you could see that would improve the inclusion of Mãori Environmental values in the RWC or a similar setting - say other comanagement or whaitua programmes? 


\title{
Appendix 2: Phase II Interview Question Guide
}

\author{
Interview Question Guide - Phase II
}

\section{Background}

- Tell me about yourself and your role with the Ruamāhanga Whaitua Committee (RWC).

- What were you reasons for joining the RWC?

- Are there any standout ideas/themes/messages you think you have learnt so far from being on the RWC?

- Tell me about the RWC's work to date.

- Have you had experience on other community based decision-making committees (or anything similar)?

- Please tell me out those experiences.

- Were there opportunities through these forums to learn about Māori worldviews and different ways of valuing the environment?

\section{Māori Environmental Values}

- Of the values so far identified by the RWC, do you agree that they are important values to the whaitua?

- If not which ones and why?

- Do you think any of the values need to have greater importance over others, and why?

- Do you think Māori environmental values are understood by everyone on the committee?

- Is there are particular reason for people not understanding?

- Why do you think this is?

\section{Māori Value Incorporation in the RWC}

- As part of the Whaitua Implementation Programme, do you feel there was adequate discussion around Māori values?

- If not do you think more discussion would be useful?

- How could such a discussion around values be improved?

- Do you feel there was adequate incorporation of Māori values in the proposed RWC recommendations for the Ruamāhanga whaitua?

- What ways do you think Māori value incorporation could be improved?

\section{Māori Value Implementation in the RWC}

- How important do you think Mãori environmental values are in the final output of the RWC recommendations to the council? 
- Do you think the Mãori values that are part of the RWC's recommendations to the council are likely to be incorporated in the final Greater Wellington Regional Council's Natural Resource Plan?

- Were enough Mãori values implementation as part of the RWC's plan?

- Do you think more could have been implemented?

- Please specify.

\section{Changes/Recommendations}

- What do you think is the main problem (if perceived to be so) facing the inclusion and/or implementation of Māori values in the RWC?

- Are there any changes you could see that would improve the inclusion of Māori Environmental values in the RWC or a similar setting - say other comanagement or whaitua programmes? 


\section{Appendix 3: Human Ethics Committee Approval}

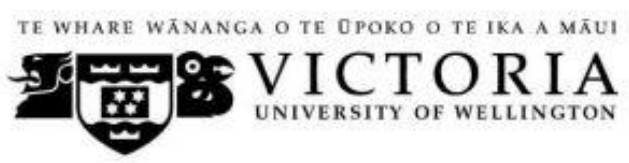

MEMORANDUM

\begin{tabular}{l|l}
\hline TO & Bryn Hickson Rowden \\
\hline COPY TO & Amanda Thomas \\
\hline FROM & AProf Susan Corbett, Convener, Human Ethics Committee \\
\hline & \\
\hline DATE & 12 June 2017 \\
\hline PAGES & 1 \\
\hline
\end{tabular}

SUBJECT $\quad$ Ethics Approval: $\mathbf{2 4 8 4 3}$

Investigating the incorporation and implementation of Maori environmental values as part of the Whaitua Implementation Programme in the Wellington Region, New Zealand/Aotearoa

Thank you for your application for ethical approval, which has now been considered by the Standing Committee of the Human Ethics Committee.

Your application has been approved from the above date and this approval continues until 27 March 2018. If your data collection is not completed by this date you should apply to the Human Ethics Committee for an extension to this approval.

Best wishes with the research.

Kind regards 


\section{Appendix 4: Phase I Participant Information Sheet}

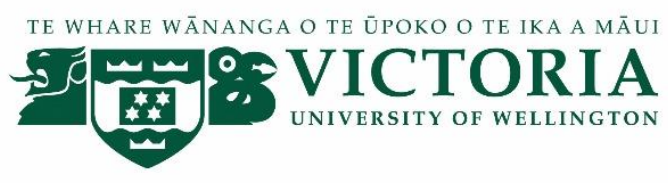

\section{Investigating the incorporation and implementation of Māori environmental values as part of the Whaitua Implementation Programme in the Wellington Region, New Zealand/Aotearoa}

INFORMATION SHEET FOR PARTICIPANTS (Phase I)

Thank you for your interest in this project. Please read this information before deciding whether or not to take part. If you decide to participate, thank you. If you decide not to take part, thank you for considering my request.

Who am I?

My name is Bryn Hickson Rowden and I am a Masters student in the Environmental Studies programme at Victoria University of Wellington. This research project is work towards my thesis.

What is the aim of the project?

This project aims to look at how Māori environmental values are viewed by, and incorporated in the Whaitua Implementation Programme.

This research has been approved by the Victoria University of Wellington Human Ethics Committee [24843].

\section{How can you help?}

If you agree to take part, I will interview you in a public place of your choosing e.g. a café or workplace meeting room. I will ask you questions about Māori environmental values in relation to the Whaitua Implementation Programme of the Ruamāhanga catchment. The interview will take 30-45 minutes. I will record the interview and write it up later. You can stop the interview at any time, without giving a reason. You can withdraw from the study by contacting me at any point before October $31^{\text {st }} 2017$. If you withdraw, the information you provided will be destroyed or returned to you.

What will happen to the information you give?

This research is confidential. This means that the researchers named below will be aware of your identity but your identity will not be disclosed in any reports, presentations, or public 
documentation (unless otherwise agreed to). However, you should be aware that in small projects your identity might be obvious to others in your community.

Only my supervisors and I will read the notes or transcript of the interview. The interview transcripts, summaries and any recordings will be kept securely and destroyed 3 years after the research ends.

\section{What will the project produce?}

The information from my research will be used in my Masters thesis and other outputs such as conference presentations and journal articles.

\section{If you accept this invitation, what are your rights as a research participant?}

You do not have to accept this invitation if you don't want to. If you do decide to participate, you have the right to:

- $\quad$ choose not to answer any question;

- $\quad$ ask for the recorder to be turned off at any time during the interview;

- $\quad$ withdraw from the study before October $31^{\text {st }} 2017$;

- $\quad$ ask any questions about the study at any time;

- $\quad$ receive a copy of your interview recording;

- be able to read any reports of this research by emailing the researcher to request a copy.

If you have any questions or problems, who can you contact?

If you have any questions, either now or in the future, please feel free to contact either:

\section{Student:}

Name: Bryn Hickson Rowden

University email address:

bryn.hicksonrowden@vuw.ac.nz

\section{Supervisor:}

Name: Amanda Thomas

Role: Lecturer in Environmental Studies

School: Geography, Environment and

Earth Sciences

Phone: +64 44636117

Email: amanda.thomas@vuw.ac.nz

\section{Human Ethics Committee information}

If you have any concerns about the ethical conduct of the research, you may contact the Victoria University HEC Convener: Associate Professor Susan Corbett. Email susan.corbett@vuw.ac.nz or telephone +64-4-463 5480. 


\title{
Appendix 5: Phase II Participant Information Sheet
}

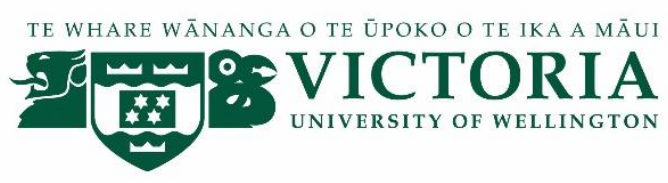

\section{Investigating the incorporation and implementation of Māori environmental values as part of the Whaitua Implementation Programme in the Wellington Region, New Zealand/Aotearoa}

\author{
INFORMATION SHEET FOR PARTICIPANTS (Phase II)
}

\begin{abstract}
Thank you for your interest in this project. Please read this information before deciding whether or not to take part. If you decide to participate, thank you. If you decide not to take part, thank you for considering my request.
\end{abstract}

Who am I?

My name is Bryn Hickson Rowden and I am a Masters student in the Environmental Studies programme at Victoria University of Wellington. This research project is work towards my thesis.

What is the aim of the project?

This project aims to look at how Māori environmental values are viewed by, and incorporated in the Whaitua Implementation Programme.

This research has been approved by the Victoria University of Wellington Human Ethics Committee [24843].

\section{How can you help?}

If you agree to take part, I will interview you in a public place of your choosing e.g. a café or workplace meeting room. I will ask you questions about Māori environmental values and their application in relation to community level environmental management decision making. The interview will take 30-45 minutes. I will record the interview and write it up later. You can stop the interview at any time, without giving a reason. You can withdraw from the study by contacting me at any point before October $31^{\text {st }} 2017$. If you withdraw, the information you provided will be destroyed or returned to you

What will happen to the information you give?

This research is confidential. This means that the researchers named below will be aware of your identity but your identity will not be disclosed in any reports, presentations, or public 
documentation (unless otherwise agreed to). However, you should be aware that in small projects your identity might be obvious to others in your community.

Only my supervisors and I will read the notes or transcript of the interview. The interview transcripts, summaries and any recordings will be kept securely and destroyed 3 years after the research ends.

\section{What will the project produce?}

The information from my research will be used in my Masters thesis and other outputs such as conference presentations and journal articles.

\section{If you accept this invitation, what are your rights as a research participant?}

You do not have to accept this invitation if you don't want to. If you do decide to participate, you have the right to:

- $\quad$ choose not to answer any question;

- $\quad$ ask for the recorder to be turned off at any time during the interview;

- $\quad$ withdraw from the study before October $31^{\text {st }} 2017$;

- $\quad$ ask any questions about the study at any time;

- $\quad$ receive a copy of your interview transcript;

- be able to read any reports of this research by emailing the researcher to request a copy.

If you have any questions or problems, who can you contact?

If you have any questions, either now or in the future, please feel free to contact either:

\section{Student:}

Name: Bryn Hickson Rowden

University email address:

bryn.hicksonrowden@vuw.ac.nz

\section{Supervisor:}

Name: Amanda Thomas

Role: Lecturer in Environmental Studies

School: Geography, Environment and

Earth Sciences

Phone: +64 44636117

Email: amanda.thomas@vuw.ac.nz

\section{Human Ethics Committee information}

If you have any concerns about the ethical conduct of the research, you may contact the Victoria University HEC Convener: Associate Professor Susan Corbett. Email susan.corbett@vuw.ac.nz or telephone +64-4-463 5480. 


\section{Appendix 6: Participant Consent Form}

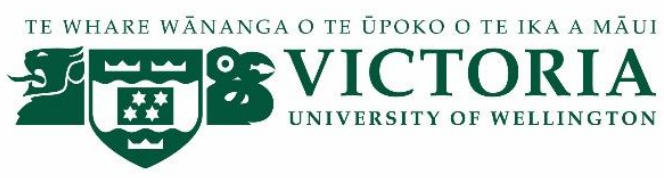

\section{Investigating the incorporation and implementation of Māori environmental values as part of the Whaitua Implementation programme in the Wellington Region, New Zealand/Aotearoa}

\section{CONSENT TO INTERVIEW}

This consent form will be held for 3 years.

Researcher: Bryn Hickson Rowden, School of Geography, Environment and Earth Sciences, Victoria University Wellington.

- I have read the Information Sheet and the project has been explained to me. My questions have been answered to my satisfaction. I understand that I can ask further questions at any time.

- I agree to take part in an audio recorded interview.

I understand that:

- I may withdraw from this study at any point before October $31^{\text {st }} 2017$, without giving any reason, and any information that I have provided will be returned to me or destroyed.

- $\quad$ The information I have provided will be destroyed 3 years after the research is finished.

- $\quad$ Any information I provide will be kept confidential to the researcher and the supervisor. I understand that the results will be used for a Masters report and a summary of the results may be used in academic reports and/or presented at conferences.

- My name will not be used in reports, nor will any information that would identify me.

- I would like a copy of the transcript of my interview:

- I would like to receive a copy of the final report and have added my email address below. 
Name of participant:

Date:

Contact details: 


\section{References}

Bell, A. (2006). Bifurcation or entanglement? Settler identity and biculturalism in Aotearoa New Zealand. Continuum, 20(2), 253-268.

Berg, L. D., \& Kearns, R. A. (1996). Naming as norming: 'Race', gender, and the identity politics of naming places in Aotearoa/New Zealand. Environment and Planning D: Society and Space, 14(1), 99-122.

Berkes, F. (2009). Evolution of co-management: Role of knowledge generation, bridging organizations and social learning. Journal of Environmental Management, 90(5), 1692-1702.

Beverley, P. (1998). The mechanisms for the protection of Maori interests under Part II of the Resource Management Act 1991. NZJ Envtl. L., 2, 121.

Bishop, R. (2011). Freeing ourselves (1 ed. Vol. 66): Sense Publishers.

Bishop, R., Berryman, M., Cavanagh, T., \& Teddy, L. (2009). Te Kotahitanga: Addressing educational disparities facing Māori students in New Zealand. Teaching and Teacher Education, 25(5), 734-742.

Blake, J. (1999). Overcoming the 'value-action gap' in environmental policy: Tensions between national policy and local experience. Local Environment, 4(3), 257278.

Briggs, J. (2005). The use of indigenous knowledge in development: Problems and challenges. Progress in Development Studies, 5(2), 99-114.

Brosius, J. P. (2004, March 17-20). What counts as local knowledge in global environmental assessments and conventions. Paper presented at the Bridging scales and knowledge systems: concepts and applications in ecosystem assessment, Alexandria, Egypt.

Brosius, J. P., Tsing, A. L., \& Zerner, C. (1998). Representing communities: Histories and politics of community-based natural resource management. Society \& Natural Resources, 11(2), 157-168.

Brosius, J. P., Tsing, A. L., \& Zerner, C. (2005). Communities and conservation: Histories and politics of community-based natural resource management: Rowman Altamira.

Burton, L., \& Cocklin, C. (1996). Water resource management and environmental policy reform in New Zealand: Regionalism, allocation, and Indigenous relations. Colorado Journal of International Environmental Law and Policy, 7(2), 331-372.

Byrnes, G. (2004). The Waitangi Tribunal and New Zealand history: Oxford University Press, USA.

Cardinal, L. (2001). What is an Indigenous perspective? Canadian Journal of Native Education, 25(2), 180-182.

Cheek, J. (2008). Foucauldian Discourse Analysis. In L. Given (Ed.), The SAGE Encylopedia of Qualitative Research Methods (Vol. 1, pp. 255-357). Thousand Oaks, California: SAGE Publications, Inc.

Cochran, P. A. L., Marshall, C. A., Garcia-Downing, C., Kendall, E., Cook, D., McCubbin, L., \& Gover, R. M. S. (2008). Indigenous ways of knowing: Implications for participatory research and community. American Journal of Public Health, 98(1), 22-27. 
Coombes, B. (2007). Postcolonial conservation and Kiekie harvests at Morere New Zealand - Abstracting Indigenous knowledge from Indigenous polities. Geographical Research, 45(2), 186-193.

Coombes, B., Johnson, J. T., \& Howitt, R. (2011). Indigenous geographies I: Mere resource conflicts? The complexities in Indigenous land and environmental claims. Progress in Human Geography, 36(6), 810-821.

Cooper, G. (2012). Kaupapa Maori research: Epistemic wilderness as freedom? New Zealand Journal of Educational Studies, 47(2), 64-73.

Council, G. W. R. (2018a). Ruamahnaga Whaitua (catchement) Committee - Terms of Reference. Wellington, New Zealand.

Council, G. W. R. (2018b, 18 January 2018). Whaitua Committees. Retrieved from http://www.gw.govt.nz/whaitua-committees/

Cunningham, C. (2000). A framework for addressing Māori knowledge in research, science and technology. Pacific Health Dialog, 7(1), 62-69.

Dahl, I. (2015). Considering environmental values during timber harvest. (Masters), Swedish University of Agricultural Sciences, Uppsala.

Davies, B., \& Gannon, S. (2005). Feminism/Poststructuralism. In B. Somekh \& C. Lewin (Eds.), Research Methods in the Social Sciences (pp. 318-325). London: SAGE Publications

Davis, D. K. (2005). Indigenous knowledge and the desertification debate: problematising expert knowledge in North Africa. Geoforum, 36(4), 509-524.

Dunn, K. (2010). 'Doing' qualitative research in human geography. In I. Hay (Ed.), Qualitative Research Methods in Human Geography (3rd ed., pp. 99-138). Oxford; New York: Oxford University Press.

Ens, E. J., Pert, P., Clarke, P. A., Budden, M., Clubb, L., Doran, B., Douras, C., Gaikwad, J., Gott, B., Leonard, S., Locke, J., Packer, J., Turpin, G., \& Wason, S. (2015). Indigenous biocultural knowledge in ecosystem science and management: Review and insight from Australia. Biological Conservation, 181, 133-149.

Fenemor, A., Phillips, C., Allen, W., Young, R. G., Harmsworth, G., Bowden, B., Basher, L., Gillespie, P. A., Kilvington, M., Davies-Colley, R., Dymond, J., Cole, A., Lauder, G., Davie, T., Smith, R., Markham, S., Deans, N., Stuart, B., Atkinson, M., \& Collins, A. (2011). Integrated catchment management-interweaving social process and science knowledge. New Zealand Journal of Marine and Freshwater Research, 45(3), 313-331.

Fernandez-Gimenez, M. E., Huntington, H. P., \& Frost, K. J. (2007). Integration or cooptation? Traditional knowledge and science in the Alaska Beluga Whale Committee. Environmental Conservation, 33(4), 306-315.

Forster, M. (2014). Indigeneity and trends in recognizing Māori environmental interests in Aotearoa New Zealand. Nationalism and Ethnic Politics, 20(1), 6378.

Getty, G. A. (2009). The journey between Western and Indigenous research paradigms. Journal of Transcultural Nursing, 21(1), 5-14.

Gibbs, L. M. (2010). "A beautiful soaking rain": environmental value and water beyond Eurocentrism. Environment and Planning D: Society and Space, 28(2), 363-378.

Gibson-Graham, J. K. (1996). The end of Capitalism (as we knew it): A feminist critique of political economy (NED - New edition ed.): University of Minnesota Press. 
Gifford, R. (2011). The dragons of inaction: psychological barriers that limit climate change mitigation and adaptation. American Psychologist, 66(4), 290.

Ginn, F. (2008). Extension, subversion, containment: eco-nationalism and (post)colonial nature in Aotearoa New Zealand. Transactions of the Institute of British Geographers, 33(3), 335-353.

Gladwin, T. N., Kennelly, J. J., \& Krause, T.-S. (1995). Shifting paradigms for sustainable development: Implications for management theory and research. Academy of management Review, 20(4), 874-907.

Glynn, T. (2015). Bicultural challenges for educational professionals in Aotearoa. Waikato Journal of Education, 20(3).

Hall, S. (1992). The West and the Rest: Discourse and power. The indigenous experience: Global perspectives, 165-173.

Harmsworth, G., Awatere, S., \& Robb, M. (2016). Indigenous Maori values and perspectives to inform freshwater management in Aotearoa-New Zealand. Ecology and Society, 21(4).

Harmsworth, G., \& Roskruge, N. (2014). Indigenous Māori values, perspectives, and knowledge of soils in Aotearoa-New Zealand beliefs and concepts of soils, the envrionment, and land In G. J. Churchman \& E. R. Landa (Eds.), The Soil Underfoot: Infinite Possibilities for a Finite Resource CRC Press.

Harris, A. (2004). Hīkoi: Forty years of Māori protest: Huia Publishers.

Hay, I. (Ed.) (2010). Qualitative Rsearch Methods in Human Geography (3rd ed.). Oxford; New York: Oxford University Press.

Henderson, J. S. Y. (2000). Ayukpachi: Empowering Aboriginal thought. In M. Battiste (Ed.), Reclaiming Indigenous voice and vision (pp. 248-278). Vancouver, Canada: Univeristy of British Columbia Press

Howitt, R., \& Stevens, S. (2010). Cross-cultural research: Ethics, methods, and relationships. In I. Hay (Ed.), Qualitative Research Methods in Human Geography (3rd ed.). Oxford; New York: Oxford University Press.

Howitt, R., \& Suchet-Pearson, S. (2006a). Ontological pluralism in contested cultural landscapes. In A. Anderson, M. Domosh, S. Pile, \& N. Thrift (Eds.), Handbook of cultural geography (pp. 557-569). London: Sage.

Howitt, R., \& Suchet-Pearson, S. (2006b). Rethinking the building blocks: Ontological pluralism and the idea of 'management'. Geografiska Annaler: Series B, Human Geography, 88(3), 323-335.

Igoe, J., \& Brockington, D. (2016). Neoliberal conservation* A brief introduction. The Environment in Anthropology: A Reader in Ecology, Culture, and Sustainable Living, 324.

Jollands, N., \& Harmsworth, G. (2007). Participation of indigenous groups in sustainable development monitoring: Rationale and examples from New Zealand. Ecological Economics, 62(3), 716-726.

Jones, A. (2012). Dangerous liaisons: Pakeha, kaupapa Maori, and educational research. New Zealand Journal of Educational Studies, 47(2), 100-112.

Joseph, R., \& Bennion, T. (2003). Challenges of incorporating Maori values and Tikanga under the resource management act 1991 and the local government billpossible ways forward. Yearbook of New Zealand Jurisprudence, 6, 9.

Kanwar, P. (2014). A regional ecological risk assessment and multijurisdictional institutional analysis of the Kaipara Harbour in New Zealand. 
Kanwar, P., Kaza, S., \& Bowden, W. B. (2016). An evaluation of Māori values in multiscalar environmental policies governing Kaipara Harbour in New Zealand. International Journal of Water Resources Development, 32(1), 26-42.

Kawharu, M. (2000). Kaitiakitanga: A Maori anthropological perspective of the Maori socio-environmental ethic of resource management. The Journal of the Polynesian Society, 109(4), 349-370.

Kepe, T. (2008). Land claims and comanagement of protected areas in South Africa: Exploring the challenges. Environmental Management, 41(3), 311-321.

Kitchin, R., \& Tate, N. J. (2000). Conducting Research into Human Geography: Theory, Methodology and Practice. Harlow, UK: Prentice Hall.

Klein, U. (2000). Belief-views on nature-Western environmental ethics and Maori world views. New Zealand Journal of Environmental Law, 4, 81-120.

Kobayashi, A. (2001). Negotiating the personal and the political in critical qualitative research. In M. Limb \& C. Dwyer (Eds.), Qualitative Methodologies for Geographers: Issues and Debates (pp. 55-72): New Yorks: Oxford University Press.

Kobayashi, A. (2003). GPC ten years on: is self-reflexivity enough? Gender, Place \& Culture, 10(4), 345-349.

Kollmuss, A., \& Agyeman, J. (2002). Mind the Gap: Why do people act environmentally and what are the barriers to pro-environmental behavior? Environmental Education Research, 8(3), 239-260.

Lacroix, K., \& Gifford, R. (2017). Psychological barriers to energy conservation behavior: The role of worldviews and climate change risk perception. Environment and Behavior, 0(0), 1-32.

Leach, M., Mearns, R., \& Scoones, I. (1999). Environmental entitlements: Dynamics and institutions in community-based natural resource management. World Development, 27(2), 225-247.

Leeuw, S. d., Cameron, E. S., \& Greenwood, M. L. (2012). Participatory and communitybased research, Indigenous geographies, and the spaces of friendship: A critical engagement. The Canadian Geographer / Le Géographe canadien, 56(2), 180194.

Local Government Act, Public Act No 84 C.F.R. (2002).

Māori Dictionary Online. Retrieved from http://maoridictionary.co.nz/

McGlone, M. S., \& Wilmshurst, J. M. (1999). Dating initial Maori environmental impact in New Zealand. Quaternary International, 59(1), 5-16.

Memon, P. A. (1997). Freshwater management policies in New Zealand. Aquatic Conservation: Marine and Freshwater Ecosystems, 7(4), 305-322.

Memon, P. A., \& Kirk, N. (2012). Role of indigenous Māori people in collaborative water governance in Aotearoa/New Zealand. Journal of Environmental Planning and Management, 55(7), 941-959.

Menchaca, M. (1997). Early racist discourses: The roots of deficit thinking. The evolution of deficit thinking: Educational thought and practice, 13-40.

Milner, H. R. (2007). Race, culture, and researcher positionality: Working through dangers seen, unseen, and unforeseen. Educational Researcher, 36(7), 388-400.

Moon, P., \& Fenton, S. (2002). Bound into a fateful union: Henry Williams' transalation of the Treaty of Waitangi into Maori in February 1840. The Journal of the Polynesian Society, 111(1), 51-63. 
Morrow, R. A., \& Brown, D. D. (1994). Critical Theory and Methodology (Vol. 3). Thousand Oaks, California: SAGE Publications, Inc.

Nadasdy, P. (2005). The anti-politics of TEK: The institutionalization of co-management discourse and practice. Anthropologica, 47(2), 215-232.

National Policy Statement for Freshwater Management (2014).

Nel, E. (2014). Evolving regional and local economic development in New Zealand. Local Economy, 30(1), 67-77.

Painter, B., \& Memon, P. A. (2008). Enhancing the potential for integrated water management in New Zealand through adaptive governance. In C. Pahl-Wostl, P. Kabat, \& J. Möltgen (Eds.), Adaptive and Integrated Water Management: Coping with Complexity and Uncertainty (pp. 227-247). Berlin, Heidelberg: Springer Berlin Heidelberg.

Palmer, L. (2006). 'Nature', place and the recognition of Indigenous polities. Australian Geographer, 37(1), 33-43.

Panelli, R., Hubbard, P., Coombes, B., \& Suchet-Pearson, S. (2009). De-centring White ruralities: Ethnic diversity, racialisation and Indigenous countrysides. Journal of Rural Studies, 25(4), 355-364.

Parsons, J., \& Harding, K. (2011). Post-colonial theory and action research. Turkish online journal of qualitative inquiry, 2(2), 1-6.

Porter, L. (2006). Planning in (post)colonial settings: Challenges for theory and practice. Planning Theory \& Practice, 7(4), 383-396.

Potter, J. (2008). Discourse analysis In L. Given (Ed.), The SAGE Encyclopedia of Qualitative Research Methods (pp. 218-220). Thousand Oaks, California: SAGE Publications, Inc. .

Prussing, E., \& Newbury, E. (2016). Neoliberalism and indigenous knowledge: Māori health research and the cultural politics of New Zealand's "National Science Challenges". Social Science \& Medicine, 150, 57-66.

Rapley, T. J. (2001). The art(fulness) of open-ended interviewing: some considerations on analysing interviews. Qualitative Research, 1(3), 303-323.

Resource Management Act, (1991).

Rexhepi, J., \& Torres, C. A. (2011). Reimagining Critical Theory. British Journal of Sociology of Education, 32(5), 679-698.

Roberts, M., Norman, W., Minhinnick, N., Wihongi, D., \& Kirkwood, C. (1995). Kaitiakitanga: Maori perspectives on conservation. Pacific Conservation Biology 2(1), 7-20.

Said, E. W. (1993). Culture and Imperialsim. London: Vintage.

Scheurich, J. J., \& Young, M. D. (1997). Coloring epistemologies: Are our research epistemologies racially biased? Educational Researcher, 26(4), 4-16.

Schewe, R. L., \& Stuart, D. (2017). Why don't they just change? Contract farming, informational influence, and barriers to agricultural climate change mitigation. Rural Sociology, 82(2), 226-262.

Shamma, T. (2018). Translation and colonialism. In S. A. Harding \& O. C. Cortes (Eds.), The Routledge Handbook of Translation and Culture: Routledge.

Smith, G. H. (2000). Protecting and respecting indigenous knowledge Reclaiming Indigenous voice and vision (pp. 209-224). Vancouver, Canada: University of British Columbia Press. 
Smith, L. T. (2005). Decolonizing Methodologies : Research and indigenous peoples. London: Zed Books.

Stefanelli, R. D., Castleden, H., Harper, S. L., Martin, D., Cunsolo, A., \& Hart, C. (2017). Experiences with integrative Indigenous and Western knowledge in water research and management: a systematic realist review of literature from Canada, Australia, New Zealand, and the United States. Environmental Reviews, 25(3), 323-333.

Stirling, A. (2014). Transforming power: Social science and the politics of energy choices. Energy Research \& Social Science, 1, 83-95.

Tapsell, P. (2002). Marae and tribal identity in urban Aotearoa/New Zealand. Pacific Studies, 25(1), 141-171.

Thomas, A. C. (2015). Indigenous more-than-humanisms: relational ethics with the Hurunui River in Aotearoa New Zealand. Social \& Cultural Geography, 16(8), 974-990.

Tipa, G. (2009). Exploring indigenous understandings of river dynamics and river flows: A case from New Zealand. Environmental Communication, 3(1), 95-120.

Tipa, G., Panelli, R., \& Moeraki Stream, T. (2009). Beyond 'someone else's agenda': An example of indigenous/academic research collaboration. New Zealand Geographer, 65(2), 95-106.

Townsend, C. R., Tipa, G., Teirney, L. D., \& Niyogi, D. K. (2004). Development of a tool to facilitate participation of Maori in the management of stream and river health. EcoHealth, 1(2), 184-195.

Valencia, R. R., \& Solórzano, D. G. (1997). Contemporary deficit thinking. The evolution of deficit thinking: Educational thought and practice, 160-210.

Waitt, G. (2010). Doing Foucauldian Discourse Analysis - Revealing social identities. In I. Hay (Ed.), Qualitative Research Methods in Human Geography (3rd ed., pp. 217240). Oxford; New York: Oxford University Press.

Walker, P. A., \& Hurley, P. T. (2004). Collaboration derailed: The politics of "community-based" resource management in Nevada County. Society \& Natural Resources, 17(8), 735-751.

Walker, R. J. (1984). The genesis of Maori activism. The Journal of the Polynesian Society, 93(3), 267-281.

Weninger, C. (2008). Critical Discourse Analysis. In L. Given (Ed.), The SAGE Encyclopedia of Qualitative Research Methods (pp. 146-148). Thousand Oaks, California: SAGE Publications, Inc.

Winchester, H. P. M., \& Rofe, M. W. (2010). Qualitative research and its place in human geography In I. Hay (Ed.), Qualitative Research Methods in Human Geography (3rd ed.): Oxford University Press.

Winchester, H. P. M., \& White, P. E. (1988). The location of marginalised groups in the inner city. Environment and Planning D: Society and Space, 6(1), 37-54.

Wink, W. (2005). Te Whiti: Maori prophet of nonviolence. Fellowship, 71(1-2), 25.

Wodak, R., \& Meyer, M. (2009). Methods for critical discourse analysis: Sage.

Workman, K. (2016). From a search for rangatiratanga to a struggle for survival Criminal justice, the state and Māori, 1985 to 2015. The 2015 JD Stout Lecture. The Journal of New Zealand Studies(22). 